\title{
Modulation of the Endocannabinoid System as a Potential Anticancer Strategy
}

\author{
Robert Ramer, Rico Schwarz and Burkhard Hinz* \\ Institute of Pharmacology and Toxicology, Rostock University Medical Center, Rostock, Germany
}

Currently, the involvement of the endocannabinoid system in cancer development and possible options for a cancer-regressive effect of cannabinoids are controversially discussed. In recent decades, a number of preclinical studies have shown that cannabinoids have an anticarcinogenic potential. Therefore, especially against the background of several legal simplifications with regard to the clinical

OPEN ACCESS

Edited by:

Marialessandra Contino,

University of Bari Aldo Moro, Italy

Reviewed by:

Antonietta Santoro,

University of Salerno, Italy

Bruno Miguel Fonseca,

Universidade do Porto, Portugal

*Correspondence:

Burkhard Hinz

burkhard.hinz@med.uni-rostock.de

Specialty section:

This article was submitted to

Experimental Pharmacology

and Drug Discovery,

a section of the journal

Frontiers in Pharmacology

Received: 20 December 2018

Accepted: 04 April 2019

Published: 09 May 2019

Citation:

Ramer R, Schwarz R and Hinz B (2019) Modulation of the

Endocannabinoid System as

a Potential Anticancer Strategy.

Front. Pharmacol. 10:430

doi: 10.3389/fphar.2019.00430 application of cannabinoid-based drugs, an extended basic knowledge about the complex network of the individual components of the endocannabinoid system is required. The canonical endocannabinoid system consists of the endocannabinoids $\mathrm{N}$-arachidonoylethanolamine (anandamide) and 2-arachidonoylglycerol as well as the $\mathrm{G}_{\mathrm{i} / \mathrm{o}}$ protein-coupled transmembrane cannabinoid receptors $\mathrm{CB}_{1}$ and $\mathrm{CB}_{2}$. As a result of extensive studies on the broader effect of these factors, other fatty acid derivatives, transmembrane and intracellular receptors, enzymes and lipid transporters have been identified that contribute to the effect of endocannabinoids when defined in the broad sense as "extended endocannabinoid system." Among these additional components, the endocannabinoid-degrading enzymes fatty acid amide hydrolase and monoacylglycerol lipase, lipid transport proteins of the fatty acidbinding protein family, additional cannabinoid-activated $G$ protein-coupled receptors such as GPR55, members of the transient receptor family, and peroxisome proliferatoractivated receptors were identified as targets for possible strategies to combat cancer progression. Other endocannabinoid-related fatty acids such as 2-arachidonoyl glyceryl ether, O-arachidonoylethanolamine, $\mathrm{N}$-arachidonoyldopamine and oleic acid amide showed an effect via cannabinoid receptors, while other compounds such as endocannabinoid-like substances exert a permissive action on endocannabinoid effects and act via alternative intracellular target structures. This review gives an overview of the modulation of the extended endocannabinoid system using the example of anticancer cannabinoid effects, which have been described in detail in preclinical studies.

Keywords: cancer, endocannabinoids, endocannabinoid-like substances, cannabinoid receptors, fatty acid amide hydrolase, monoacylglycerol lipase 


\section{INTRODUCTION}

The endocannabinoid system encompasses the two "classical" endocannabinoids, $\mathrm{N}$-arachidonoylethanolamine (anandamide, AEA) and 2-arachidonoylglycerol (2-AG), and the cannabinoid receptors $\mathrm{CB}_{1}$ and $\mathrm{CB}_{2}$. In recent years, further components have expanded this original definition of the endocannabinoid system. These components comprise newly discovered endogenous cannabinoid receptor ligands such as 2-arachidonoyl glyceryl ether (noladin ether, 2-AGE), O-arachidonoylethanolamine (virodhamine), $N$-arachidonoyldopamine (NADA), oleic acid amide (oleamide, OA) as well as further receptor targets such as $\mathrm{G}$ protein-coupled receptor (GPR) 55 and peroxisome proliferatoractivated receptors (PPARs) (Iannotti et al., 2016). Moreover, the cation channel transient receptor potential vanilloid 1 (TRPV1) has been described as an additional receptor, activated by AEA (Zygmunt et al., 1999).

As further parts of the endocannabinoid network, endocannabinoid-synthesizing and -degrading enzymes play a pivotal role in cellular signaling. Accordingly, $N$-acyl-phosphatidylethanolamine-specific phospholipase D (NAPE-PLD), a/b-hydrolase domain-containing protein 4 (ABDH4), glycerophosphodiesterase-1 (GDE1) and tyrosine-protein phosphatase non-receptor type 22 (PTPN22) were identified as AEAsynthesizing enzymes. Diacylglycerol lipase a and -b (DAGL a and -b) were identified as the main 2-AG-producing enzymes. Conversely, AEA and 2-AG were shown to be degraded by fatty acid amide hydrolase (FAAH) with 2-AG being predominantly hydrolyzed by monoacylglycerol lipase (MAGL) (for review, see Di Marzo, 2009; Petrosino and Di Marzo, 2010).

In addition to the palliative effects of cannabinoid compounds in cancer treatment, the endocannabinoid system provides several targets for systemic anticancer treatment. Accordingly, preclinical studies suggest cannabinoids inhibit cancer progression via inhibition of cancer cell proliferation, neovascularization, invasion and chemoresistance, as well as induction of apoptosis, autophagy and increase of tumor immune surveillance (for review, see Schwarz et al., 2018). The following chapters focus on the different levels of anticancer effects of cannabinoids and the role of components of the endocannabinoid system within this process. An overview of important elements of the endocannabinoid system is provided in Figure $\mathbf{1}$.

\section{REGULATION OF CANNABINOID RECEPTORS IN MALIGNANT TISSUE}

The scientific basis of the endocannabinoid system was established with the discovery and cloning of a central seven-transmembrane $G$ protein-coupled cannabinoid receptor, referred to as $\mathrm{CB}_{1}$ (Matsuda et al., 1990). Subsequently, the discovery of the peripheral $\mathrm{CB}_{2}$ receptor on spleen and blood cells followed in 1993 (Munro et al., 1993). Initial analysis of intracellular pathway coupling revealed both receptors to act via pertussis toxin-sensitive $G_{i / o}$ protein interaction, resulting in inhibition of adenylyl cyclase activity and thus intracellular reduction of cAMP levels (Das et al., 1995; Slipetz et al., 1995).
Concerning the regulation of cannabinoid receptors in malignant tissue, a number of investigations provided evidence for an upregulation of cannabinoid receptors in cancer tissue (for review, see Ramer and Hinz, 2016). In this context, a correlation between high $\mathrm{CB}_{1}$ receptor expression and poor prognosis for patients with pancreatic (Michalski et al., 2008), prostate (Chung et al., 2009), ovarian (Messalli et al., 2014), colorectal cancers (Jung et al., 2013) and renal cell carcinoma (Wang J. et al., 2016) was shown. However, concerning renal carcinomas, $\mathrm{CB}_{1}$ receptor expression was found to appear downregulated in clear cell renal cell carcinoma (Larrinaga et al., 2010) as well as in chromophobe renal cell carcinoma and renal oncocytoma (Larrinaga et al., 2013).

In terms of higher $\mathrm{CB}_{2}$ receptor expression, a link to poor prognosis for patients with HER2-positive breast cancer (Pérez-Gómez et al., 2015), as well as for head and neck squamous cell carcinoma (HNSCC) (Klein Nulent et al., 2013) was demonstrated. Furthermore, immunohistochemical analyses of biopsies from human astrocytoma revealed detectable cannabinoid receptors $\left(\mathrm{CB}_{1}\right.$ and/or $\left.\mathrm{CB}_{2}\right)$ in $70 \%$ of all cases (Sánchez et al., 2001). Notably, analyses of the $\mathrm{CB}_{2}$ receptors exhibited a significant number of biopsies with high/very high expression of $\mathrm{CB}_{2}$ receptors in grade IV astrocytoma versus grade I-III astrocytoma suggesting the $\mathrm{CB}_{2}$ receptor expression to correlate with malignancy. Another comprehensive study that addressed the regulation of cannabinoid receptors in hepatocellular carcinoma found high expression of both $\mathrm{CB}_{1}$ and $\mathrm{CB}_{2}$ receptors in $45 \%$ and $52 \%$ of all cancer tissue samples by immunohistochemical analyses, respectively (Xu et al., 2006). Here, the authors showed high $\mathrm{CB}_{1}$ receptor expression in $87 \%$ of well-differentiated cancers and high $\mathrm{CB}_{2}$ receptor expression in $100 \%$ of well-differentiated cancers versus low expression of the $\mathrm{CB}_{1}$ as well as the $\mathrm{CB}_{2}$ receptor in $73 \%$ of poorly differentiated cancers, respectively. These findings correspond to the mRNA levels assessed by in situ hybridization, suggesting that expression of cannabinoid receptors decreased according to cell differentiation. Disease-free survival was significantly improved for patients with hepatocellular carcinoma that exhibited high $\mathrm{CB}_{1}$ and $\mathrm{CB}_{2}$ expression as compared to those with low cannabinoid receptor expressions. Concerning the regulation of cannabinoid receptors in glioma, another study that assessed cannabinoid receptor expression in malignant tissue was able to demonstrate detectable $\mathrm{CB}_{2}$ in three out of six low-grade gliomas but in all high-grade gliomas (Calatozzolo et al., 2007). In the latter study, two out of six low-grade gliomas and five out of eight high-grade gliomas were positive to $\mathrm{CB}_{1}$. Furthermore, a recent study found $\mathrm{CB}_{2}$ to be upregulated in renal cell carcinoma. Here a tendency of higher $\mathrm{CB}_{2}$ expression was associated with poor clinical outcome (Wang et al., 2018).

An important contribution to $\mathrm{CB}_{1}$ receptor regulation in cancer tissue may apparently be epigenetic regulations. A recent investigation on colon cancer progression found CNR1 methylation increased at $\mathrm{CpG}$ islands surrounding the promoter region, whereas it was decreased in the body of the gene in tumor samples. The authors further found $\mathrm{CB}_{1} \mathrm{mRNA}$ to appear upregulated in non-tumor tissue and downregulated in tumor tissue (Hasenoehrl et al., 2018). Another study confirmed 


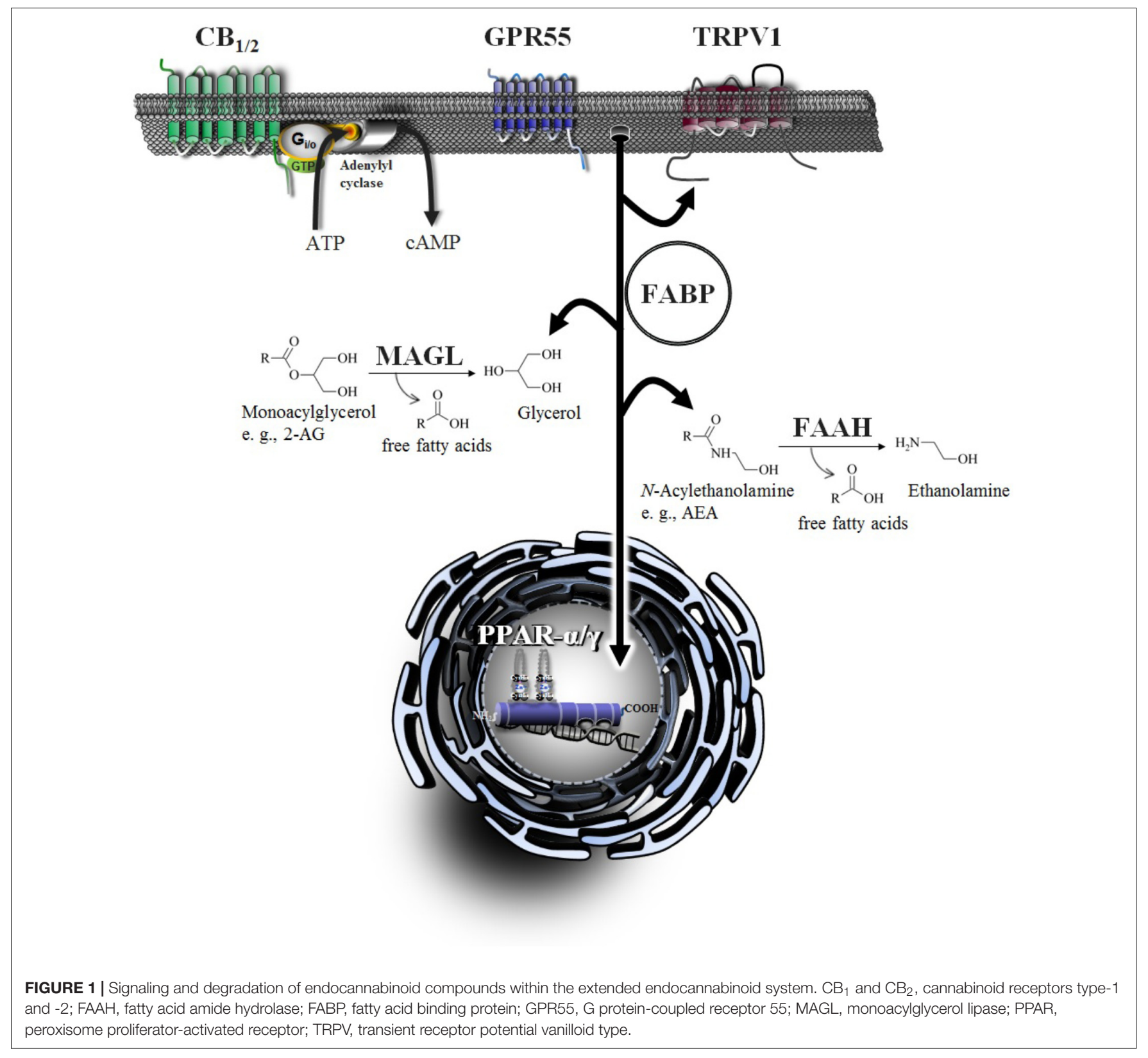

epigenetic hypermethylation of the CNR1 promoter that results in reduced transcription (Wang D. et al., 2008). Analyses of patients' specimens here revealed $\mathrm{CB}_{1}$ mRNA and protein to appear drastically reduced in cancer tissue as compared with normal mucosa.

\section{ENDOCANNABINOIDS AND ENDOCANNABINOID-LIKE SUBSTANCES}

The first endogenously synthesized compounds proven to act at cannabinoid receptors were AEA (Devane et al., 1992) and 2-AG (Mechoulam et al., 1995). AEA was identified as a partial agonist at the $\mathrm{CB}_{1}$ with a receptor affinity comparable to that of the phytocannabinoid $\Delta^{9}$-THC (Devane et al., 1992; Mackie et al., 1993; Sugiura et al., 1999; Di Marzo and De Petrocellis, 2012), while being almost inactive at the $\mathrm{CB}_{2}$ receptor (Gonsiorek et al., 2000; Sugiura et al., 2000; Di Marzo and De Petrocellis, 2012). 2AG, however, was shown to exert full agonist properties with a moderate affinity at both cannabinoid receptors (Sugiura et al., 1999, 2000; Gonsiorek et al., 2000; Savinainen et al., 2001).

As has been proven for the cannabinoid receptors, the levels of endocannabinoids in malignant tissue were likewise shown to be elevated. Accordingly, concentrations of AEA and 2-AG were found to be increased in adenomatous polyps and in colorectal carcinomas when compared with healthy neighboring tissue (Ligresti et al., 2003). In agreement with this finding, increases of endocannabinoid concentrations were detected in pituitary adenomas (Pagotto et al., 2001), in prostate 
(Schmid et al., 2002; Nithipatikom et al., 2004) and colorectal cancers (Chen et al., 2015), as well as in meningiomas and glioblastomas (Petersen et al., 2005).

With respect to the functional implication of endocannabinoids in tumor progression, as early as two decades ago AEA was shown to confer a concentration-dependent inhibitory effect (maximal inhibition at $10 \mu \mathrm{M}$ ) on the proliferation of nerve growth factor-activated breast cancer cells via activation of $\mathrm{CB}_{1}$ receptors and downstream inhibition of endogenous prolactin action (De Petrocellis et al., 1998). Another early investigation on that topic confirmed the involvement of the $\mathrm{CB}_{1}$ receptor in the AEA-induced inhibition of nerve growth factor-activated breast and prolactin-activated prostate cancer cell proliferation (Melck et al., 2000). Later investigations were able to further verify this anticancer effect. Accordingly, AEA in the range of 0.01 to 10 $\mu \mathrm{M}$ was found to elicit an antiproliferative action on glioma cells via both cannabinoid receptors and TRPV1 by enhancing downstream oxidative stress and calpain activation (Jacobsson et al., 2001). Inhibition of colon carcinoma cell proliferation by AEA at $1 \mu \mathrm{M}$ was reversed by an antagonist to $\mathrm{CB}_{1}$, but not $\mathrm{CB}_{2}$ (Ligresti et al., 2003). Using epidermal growth factor (EGF)-activated prostate cancer cells, another study was able to demonstrate AEA to inhibit proliferation by downregulation of EGF receptor expression via upstream activation of the $\mathrm{CB}_{1}$ receptor (Mimeault et al., 2003). Besides this antiproliferative action, AEA was further shown to inhibit lung cancer cell invasion and metastasis via upregulation of tissue inhibitor of matrix metalloproteinases-1 (TIMP-1) (Winkler et al., 2016) and to induce apoptosis in human gastric adenocarcinoma (Ortega et al., 2016). Moreover, AEA was demonstrated to induce a cyclooxygenase-2 (COX-2)-dependent cell death in apoptosisresistant colon cancer cells at a concentration of $25 \mu \mathrm{M}$ devoid of $\mathrm{CB}_{1}$ and $\mathrm{CB}_{2}$ receptor activation (Patsos et al., 2010). In contrast to these findings, another investigation could not confirm a contribution of COX-2 to the AEA-induced apoptosis of HNSCC cell lines (Park et al., 2015). In this study, a high concentration of AEA $(20 \mu \mathrm{M})$ was shown to induce apoptosis via enhanced oxidative stress bypassing cannabinoid-activated receptors. In an investigation that addressed the cytotoxic effect of AEA on malignant melanoma cells, a decrease of AEA-induced cytotoxicity was observed in the presence of the selective COX-2 inhibitor rofecoxib and the lipoxygenase (LOX) inhibitor caffeic acid (Adinolfi et al., 2013). In addition, the authors were able to demonstrate a rightward shift of the concentration-response curve of $\mathrm{AEA}$ in the presence of the $\mathrm{CB}_{1}$ receptor antagonist AM-251 and the TRPV1 antagonist capsazepine. Accordingly, the AEA-induced loss of viability appeared with an $\mathrm{IC}_{50}$ level of $5.8 \pm 0.7 \mu \mathrm{M}$ that was shifted up to $10.9 \pm 0.6 \mu \mathrm{M}$ and $8.2 \pm 0.4 \mu \mathrm{M}$ in the presence of AM-251 and capsazepine, respectively, indicating at least a partial contribution of the $\mathrm{CB}_{1}$ receptor to the toxic effect of AEA on melanoma cells. Concerning the anticarcinogenic effect on glioblastoma cells, another investigation found AEA to inhibit proliferation, to accumulate cells in the $G_{0} / G_{1}$ phase, to reduce percentage of cells in the $G_{2} / M$ phase, to inhibit cellular migration and to induce apoptosis within a concentration range from 1 to $10 \mu \mathrm{M}$ in a concentration dependent manner (Ma et al., 2016). Concerning the involvement of cannabinoid-activated receptors, there is a tendency for receptor-independent effects of AEA when tested at concentrations $>10 \mu \mathrm{M}$.

Furthermore, several AEA derivates have been demonstrated to likewise exert anticancer properties. Accordingly, arachidonoyl-2'-chloroethylamide (ACEA) was found to cause antiproliferative effects on colorectal carcinoma cells at concentrations ranging from 0.01 to $1 \mu \mathrm{M}$ (Ligresti et al., 2003). Two other AEA derivates with proven anticancer properties are $\mathrm{R}(+)$-methanandamide and 2-methyl-arachidonyl-2'-fluoroethylamide (Met-F-AEA). R(+)-methanandamide $(10 \mu \mathrm{M})$ was shown to elicit apoptosis via a mechanism bypassing cannabinoid and TRPV1 activation (Hinz et al., 2004; Eichele et al., 2006, 2009) in cervical and lung cancer as well as glioma cells. However, an involvement of $\mathrm{CB}_{1}$ and $\mathrm{CB}_{2}$ receptors on mantle cell lymphoma apoptosis (Gustafsson et al., 2006) and of $\mathrm{CB}_{1}$ on apoptosis of prostate cancer cells (Orellana-Serradell et al., 2015) was demonstrated. Induction of apoptosis by $\mathrm{R}(+)$-methanandamide at a concentration of $5 \mu \mathrm{M}$ was further confirmed in gastric cancer cells (Ortega et al., 2016). In addition, $\mathrm{R}(+)$-methanandamide caused a cannabinoid receptor- and TRPV1-dependent inhibition of cervical and lung cancer cell invasion (Ramer and Hinz, 2008) and an enhancement of lung cancer cell killing by lymphokine-activated killer cells in a coculture system via upregulation of the intercellular adhesion molecule 1 (ICAM-1), the counterreceptor of the lymphocytefunction-associated antigen 1 (LFA-1) on the surface of killer cells (Haustein et al., 2014). A contribution of the $\mathrm{CB}_{1}$ receptor to the cancer growth-inhibitory action of Met-F-AEA $(10 \mu \mathrm{M})$ was demonstrated using ras oncogene-dependent tumor cells (Bifulco et al., 2001) and colorectal cancer cells (Proto et al., 2012). Moreover, Met-F-AEA caused inhibition of metastasis of Lewis lung carcinoma (Portella et al., 2003) and breast cancer (Grimaldi et al., 2006). In addition, a cell cycle arrest by suppression of Cdk2 activity could be proven for Met-F-AEA in breast cancer cells (Laezza et al., 2006). The same investigators later described $10 \mu \mathrm{M}$ Met-F-AEA to reduce the expression of $\beta$-catenin protein and its accumulation in the nuclei of breast cancer cells via $\mathrm{CB}_{1}$ receptor activation associated with downregulation of c-Myc, matrix metalloproteinase-2 (MMP-2) and cyclin D1 (Laezza et al., 2012). The latter study further found Met-F-AEA to cause downregulation of mesenchymal markers such as vimentin, fibronectin and $\mathrm{N}$-cadherin by induction of E-cadherin and upregulation of the markers indicating epithelial-to-mesenchymal transition such as Snail, Slug, and Twist in breast cancer cells.

Similar to AEA, 2-AG was likewise demonstrated to exert considerable anticancer properties. Accordingly, activation of the $\mathrm{CB}_{1}$ receptor could be proven to contribute to the antiproliferative action of 2-AG on nerve growth factorstimulated breast cancer cells (Melck et al., 2000) and to its proapoptotic action on prostate cancer cells (Orellana-Serradell et al., 2015) when using 2-AG concentrations in the range of $0.5-5 \mu \mathrm{M}$ and $5 \mu \mathrm{M}$, respectively.

Other cancer entities sensitive toward 2-AG are colorectal carcinoma (Ligresti et al., 2003) and glioma cells (Jacobsson et al., 2001). A recent study was able to demonstrate 
2-AG to inhibit lung cancer cell invasion in a concentration dependent manner (0.01-10 $\mu \mathrm{M}$ ) (Winkler et al., 2016) and to further decrease metastasis in vivo. Finally, 2-AG was proven to inhibit proliferation (Nithipatikom et al., 2011) and invasion (Nithipatikom et al., 2004) of prostate carcinoma cells.

Concerning the molecular effects of endogenously synthesized cannabinoid compounds beyond the two classical endocannabinoids AEA and 2-AG, ambivalent data have been published so far. An early study revealed NADA to exert preferential 40 -fold higher affinity to the $\mathrm{CB}_{1}\left(K_{\mathrm{i}}\right.$ value of 250 $n M$ ) compared to $\mathrm{CB}_{2}$ receptors (Bisogno et al., 2000). However, another study could not find NADA to act as $\mathrm{CB}_{1}$ agonist but to enhance mobilization of calcium via $G_{\mathrm{q}}$ protein-dependent processes (Redmond et al., 2016). Another investigation was able to provide evidence for NADA to elicit intracellular calcium increase via TRPV1 (Huang et al., 2002). As further mode of action, NADA may also inhibit FAAH activity with an $\mathrm{IC}_{50}$ value of $23 \mu \mathrm{M}$, thereby causing increased levels of classical endocannabinoids (Bisogno et al., 2000). Noladin ether was shown to act as an agonist at the $\mathrm{CB}_{1}$ and $\mathrm{CB}_{2}$ receptors and as partial TRPV1 agonist (Hanus et al., 2001; Duncan et al., 2004). In contrast, virodhamine was found to function as a $\mathrm{CB}_{1}$ receptor antagonist and $\mathrm{a}_{2}$ receptor agonist (Porter et al., 2002). As has been demonstrated for NADA, virodhamine was likewise described as a FAAH inhibitor ( $\mathrm{IC}_{50}$ value of $13.8 \mu \mathrm{M}$ ) (Steffens et al., 2005) and furthermore as an inhibitor of MAGL (Brantl et al., 2014). Other substances shown to act as cannabinoid receptor agonists are $N$-docosahexaenoylethanolamine (DHEA) and $N$-eicosapentaenoylethanolamine (EPEA) (Brown et al., 2010). A possible common mode of action discussed for the endocannabinoids AEA and 2-AG, as well as for NADA, noladin ether and virodhamine, may lie in their agonistic action at GPR55 (Ryberg et al., 2007; Akimov et al., 2017). EC 50 values of the endocannabinoids were found in a low-nanomolar range (3 nM for 2-AGE, up to $18 \mathrm{nM}$ for AEA) at the GPR55, which even appeared lower than those evaluated for the $\mathrm{CB}$ receptors (lowest values measured for AEA were $31 \mathrm{nM}$ at the $\mathrm{CB}_{1}$ and $27 \mathrm{nM}$ at $\mathrm{CB}_{2}$ ) (Ryberg et al., 2007).

$N$-Palmitoylethanolamine (PEA), N-oleoylethanolamine (OEA), and $N$-stearoylethanolamine (SEA) are referred to as cannabinoid-like substances that do not elicit cannabinoid receptor activation (Bisogno et al., 1998; Maccarrone et al., 2002). Among these, PEA was demonstrated to permissively enhance AEA effects by downregulation of FAAH expression and activity and via positive allosteric modulation of TRPV1, which was termed the "entourage effect" (Di Marzo et al., 2001; De Petrocellis et al., 2002). Currently, the available data concerning the regulation of endocannabinoid-like substances in cancer tissue is limited. One study was able to demonstrate lower levels of OEA and PEA associated with a downregulation of AEA but not with 2-AG in human meningiomas and gliomas (Maccarrone et al., 2001). Another investigation demonstrated higher plasma concentrations of circulating OEA to correlate with higher numbers of metastases in several cancer entities (Sailler et al., 2014). An overview on the regulation of endocannabinoids and endocannabinoid-like substances in cancer tissue is provided in Table 1.
TABLE 1 | Regulation of endocannabinoids and endocannabinoid-like substances in cancer tissue.

\begin{tabular}{|c|c|c|c|}
\hline Tumor & References & Endocannabinoid & Regulation \\
\hline \multirow{4}{*}{$\begin{array}{l}\text { Colorectal } \\
\text { carcinoma }\end{array}$} & Ligresti et al., 2003 & 2-AG & $\uparrow$ \\
\hline & & AEA & \\
\hline & Chen et al., 2015 & AEA & $\uparrow$ \\
\hline & & 2-AG & $\leftrightarrow$ \\
\hline \multirow{2}{*}{$\begin{array}{l}\text { Diffuse large } \\
\text { B-cell lymphoma }\end{array}$} & Zhang et al., 2016 & $2-\mathrm{AG}^{\mathrm{a}}$ & $\uparrow$ \\
\hline & & $2-O G^{a}$ & \\
\hline \multirow{3}{*}{$\begin{array}{l}\text { Endometrial } \\
\text { carcinoma }\end{array}$} & Guida et al., 2010 & 2-AG & $\uparrow$ \\
\hline & & AEA & $\leftrightarrow$ \\
\hline & & PEA & \\
\hline \multirow[t]{10}{*}{ Glioma } & Maccarrone et al., 2001 & AEA & $\downarrow$ \\
\hline & & OEA & \\
\hline & & PEA & \\
\hline & & SEA & \\
\hline & & 2-AG & $\leftrightarrow$ \\
\hline & Petersen et al., 2005 & AEA & $\uparrow$ \\
\hline & & 2-AG & $\leftrightarrow$ \\
\hline & Wu et al., 2012 & AEA ${ }^{b}$ & $\downarrow$ \\
\hline & & $2-A G^{b}$ & $\uparrow$ \\
\hline & & OEA & $\leftrightarrow$ \\
\hline $\begin{array}{l}\text { Hepatocellular } \\
\text { carcinomas }\end{array}$ & $\begin{array}{l}\text { Mukhopadhyay et al., } \\
2015\end{array}$ & AEA & $\uparrow$ \\
\hline \multirow[t]{7}{*}{ Meningioma } & Maccarrone et al., 2001 & AEA & $\downarrow$ \\
\hline & & OEA & \\
\hline & & PEA & \\
\hline & & SEA & \\
\hline & & 2-AG & $\leftrightarrow$ \\
\hline & Petersen et al., 2005 & AEA & $\leftrightarrow$ \\
\hline & & 2-AG & $\uparrow$ \\
\hline \multirow{2}{*}{$\begin{array}{l}\text { Pituitary } \\
\text { adenomas }\end{array}$} & Pagotto et al., 2001 & AEA & $\uparrow$ \\
\hline & & 2-AG & \\
\hline \multirow[t]{4}{*}{ Various cancers $^{d}$} & Sailler et al., 2014 & $\mathrm{AEA}^{\mathrm{C}}$ & $\downarrow$ \\
\hline & & $2-A G^{C}$ & $\uparrow$ \\
\hline & & $\mathrm{PEA}^{\mathrm{C}}$ & $\leftrightarrow$ \\
\hline & & $\mathrm{OEA}^{\mathrm{C}}$ & \\
\hline
\end{tabular}

$\leftrightarrow$, not regulated; $\uparrow$, upregulated; $\downarrow$, downregulated; ${ }^{a}$, measured in patients' serum; ' , associated with advanced disease stages; ' ', measured in patients' plasma; ' , endocannabinoids measured in plasma from breast, prostate, lung, pancreatic, skin, hematological, gynecological, and other unnamed cancers; 2-AG, 2-arachidonoylglycerol; 2-OG, 2-oleoylglycerol; $A E A, N$-arachidonoylethanolamine (anandamide); OEA, N-oleoylethanolamine; PEA, N-palmitoylethanolamine; SEA, $\mathrm{N}$-stearoylethanolamine. If no arrow is indicated, the regulation of the endocannabinoid above applies.

The data concerning effects of cannabinoid agonists such as NADA, noladin ether, and virodhamine or cannabinoid-like substances on tumor progression are currently still limited. An early investigation found NADA to elicit inhibition of breast cancer cell proliferation in vitro $\left(\mathrm{IC}_{50}\right.$ value of $0.25 \mu \mathrm{M}$ ) and in vivo (Bisogno et al., 2000). Furthermore, a recent study demonstrated antiproliferative and cell death-inducing properties for NADA in human osteosarcoma, neuroblastoma, breast adenocarcinoma, lymphoma, and leukemia cell lines when 
tested at micromolar concentrations (Akimov et al., 2015). Concerning the mode of action, NADA (1 $\mu \mathrm{M})$ has been found to confer antiproliferative effects on colorectal carcinoma cells via activation of $\mathrm{CB}_{1}$ (Ligresti et al., 2003). In terms of pheochromocytoma cells, an antagonist to GPR55 was able to counteract NADA-induced cell death (Akimov et al., 2017), whereas cell death of neuroblastoma cells by NADA was mediated by TRPV1 activation (Davies et al., 2010). Noladin ether was shown to confer inhibition of prostate cancer cell proliferation (1-50 $\mu \mathrm{M})$ via nuclear factor $(\mathrm{NF})-\kappa \mathrm{B} /$ cyclin $\mathrm{D}$ - and cyclin E-dependent pathways (Nithipatikom et al., 2011). The antiinvasive action of noladin ether was mediated by downregulation of protein kinase A activity (Nithipatikom et al., 2004). In contrast, nothing is yet known about the anticarcinogenic effects of virodhamine.

Concerning the effects of fatty acid ethanolamides belonging to the group of endocannabinoid-like substances, OEA and PEA were found to elicit decreased viability of neuroblastoma cells at a concentration of $10 \mu \mathrm{M}$ (Hamtiaux et al., 2011) and to inhibit invasion and metastasis of lung cancer cells (Winkler et al., 2016). In the case of OEA, the latter study reported that the antiinvasive action was reversed by knockdown of TIMP-1. PEA was shown to inhibit colon carcinoma cell proliferation by inhibition of the Akt/mechanistic target of rapamycin (mTOR) pathway that involves PPAR $\alpha$ (Sarnelli et al., 2016), to enhance inhibition of proliferation by AEA by virtue of its action as positive allosteric modulator of TRPV1 (De Petrocellis et al., 2002) and to permissively enhance AEA effects by downregulation of FAAH expression and activity (Di Marzo et al., 2001). A similar entourage effect was reported for SEA (Maccarrone et al., 2002), which has also been found to elicit proapoptotic effects in rat glioma cells by increasing intracellular calcium levels and mitochondrial uncoupling (Maccarrone et al., 2002). Conversely, a recent study reported enhanced migration of melanoma cancer cells as result of treatment with OEA (Sailler et al., 2014). Antiproliferative properties were observed in prostate cancer cells treated with DHEA and EPEA (Brown et al., 2010). In this context, DHEA and EPEA-induced toxicity was found to be associated with increased autophagy in breast cancer cells (Rovito et al., 2013). In addition, a contribution of the LOX pathway was demonstrated for the antiproliferative action of DHEA and $N$-arachidonoyl-L-alanine (NALA) at concentrations of $20 \mu \mathrm{M}$ each on HNSCC cells (Park et al., 2016). Accordingly, the antiproliferative action of DHEA and NALA was not reversed by the $\mathrm{CB}_{1}$ receptor antagonist/inverse agonist AM-251 and the TRPV1 antagonist CAY10448, but by the inhibitors of 5-lipoxygenase (5-LO), AA861, zileuton, ebselen as well as by knockdown of 5-LO using an siRNA approach. As a mechanistic basis of this effect the authors assumed a decrease of the phosphorylated form of Akt by reactive oxygen species generated upon catabolism of DHEA and NALA via 5-LO.

\section{TRP CHANNELS}

Among the transient receptor potential (TRP) family, TRPV1 emerged as an additional "ionotropic cannabinoid receptor"
(Di Marzo et al., 2002) that was found to be activated by AEA (Zygmunt et al., 1999) and the non-psychoactive phytocannabinoid cannabidiol (CBD) (Bisogno et al., 2001; Ligresti et al., 2006). Further TRP channels modulated by cannabinoid compounds are TRPV2, which was reported to be activated by CBD (Qin et al., 2008; Nabissi et al., 2013) and $\Delta^{9}$-THC (De Petrocellis et al., 2011) as well as the CBD- and tetrahydrocannabivarin-triggered TRPV3 (De Petrocellis et al., 2012). TRPV3 and TRPV4 were further found to be desensitized by cannabigerovarin and cannabigerolic acid (De Petrocellis et al., 2008). Cannabigerol, CBD, and cannabinol were additionally identified as activators of TRP channels of the ankyrin type-1 (TRPA1) and the melastatin type8 (TRPM8), with the latter receptor also being activated by $\Delta^{9}$-THC acid (De Petrocellis et al., 2008).

Among the large number of members of the TRP family, the contribution of TRPV1 to the anticancerogenic effects of cannabinoids is the most comprehensively investigated issue. Accordingly, TRPV1 was shown to be upregulated in malignant prostate cancer tissue (Czifra et al., 2009). Anticancer effects of AEA were described to be mediated via TRPV1 in a number of early studies. As such, AEA was found to induce apoptosis in neuroblastoma, lymphoma (Maccarrone et al., 2000) and cervical cancer cells (Contassot et al., 2004) and to inhibit glioma cell proliferation (Jacobsson et al., 2001) via TRPV1 activation. Inhibition of breast cancer cell proliferation by CBD was further found to be partially mediated via TRPV1 (Ligresti et al., 2006). A causal contribution of TRPV1 to the anti-invasive impact of $\mathrm{R}(+)$-methanandamide on cervical and lung cancer cells was shown to be mediated by upregulation of TIMP-1 (Ramer and Hinz, 2008). A similar anti-invasive TRPV1-dependent impact on lung cancer cells could be proven for FAAH siRNA and the FAAH inhibitors URB597 and $N$-arachidonoylserotonin (AA-5HT) (Winkler et al., 2016), as well as for CBD (Ramer et al., 2012). CBD was further demonstrated to reduce cancerogenesis in an azoxymethane-induced colon cancer model. Here, accompanying in vitro experiments showed an involvement of TRPV1 in the antiproliferative action of CBD on colon cancer cells (Aviello et al., 2012). In a recent investigation TRPV1 was finally shown to contribute to the toxicity of AEA and CBD on endometrial adenocarcinoma cells (Fonseca et al., 2018).

According to a recent investigation, TRPM8 inhibition by cannabigerol may represent another mechanism for inhibition of colon carcinogenesis (Borrelli et al., 2014). Furthermore, recent studies suggest TRPV2 to act as key regulator of glioma cell autophagy induced upon CBD treatment (Nabissi et al., 2015) and as mediator of a cannabinoid-induced sensitivity of cancer cells toward chemotherapeutics (Nabissi et al., 2013; Morelli et al., 2014).

\section{G PROTEIN-COUPLED RECEPTORS}

Several investigations of recent years have described a number of $\mathrm{G}$ protein-coupled receptors (GPRs) activated or inhibited by cannabinoid treatment. 
Accordingly, GPR55 was found to be activated by the synthetic regioisomer of CBD, abnormal-CBD (abn-CBD), the specific GPR55 agonist structurally related to cannabinoids, O-1602, as well as by $\mathrm{R}(+)$-methanandamide, $\Delta^{9}$-THC and the specific $\mathrm{CB}_{2}$ receptor agonist JWH-015 (Johns et al., 2007; Lauckner et al., 2008). In agreement with these findings, AEA and virodhamine were described as cannabinoid compounds acting as agonists at GPR55, whereas CBD was revealed as a GPR55 antagonist (Ryberg et al., 2007). A further receptor target of cannabinoid action among the GPRs may be GPR18, which has been shown to be activated by $N$-arachidonoylglycine (NAGly), O-1602, abnCBD, $\Delta^{9}$-THC and AEA (McHugh et al., 2012). However, several studies did not confirm these results concerning the activity of NAGly, AEA and abn-CBD at GPR18 (Yin et al., 2009; Lu et al., 2013; Finlay et al., 2016). Thus, the definition of GPR18 as a cannabinoid-activated receptor has to be evaluated critically. With respect to other GPRs as members of the endocannabinoid system in an extended definition, OEA and PEA were found to modulate GPR119 (Overton et al., 2006), NAGly was revealed to exert binding to GPR92 (Oh et al., 2008) and finally CBD was found to act as inverse agonist at GPR12 (Brown et al., 2017).

Regarding a possible role in cancer regression by cannabinoid action, GPR55 emerged as a promising target. Notably, GPR55 has been found to be a receptor conferring cancerogenesis when activated with lysophosphatidylinositol (LPI) (Henstridge et al., 2011; Ross, 2011). In agreement with this notion, high GPR55 mRNA expression in tumor tissue of patients with colorectal carcinomas was described to be significantly associated with reduced relapse-free survival (Hasenoehrl et al., 2018). Accordingly, GPR55 mRNA expression levels revealed a downregulation that was associated with increasing TNM stages. The latter investigation further found reduced colorectal carcinogenesis in GPR55 knockout mice. In line with this, several cannabinoids were demonstrated to counteract GPR55 action. Accordingly, CBD acting as GPR55 antagonist was shown to inhibit colon cancerogenesis (Kargl et al., 2016; Hasenoehrl et al., 2018). Furthermore, a crosstalk between $\mathrm{CB}_{2}$ receptors and GPR55 was identified as a determinant of cancer progression (Moreno et al., 2014).

\section{MEMBERS OF THE PPAR FAMILY}

In the context of direct modulations of PPARs, the endocannabinoid-like substances EPEA, DHEA, SEA, OEA, and PEA are currently discussed as PPAR $\alpha$ agonists (Fu et al., 2003; Lo Verme et al., 2005; Artmann et al., 2008; Tellez et al., 2013). Regarding the effect of $\Delta^{9}$-THC on PPAR $\alpha$, one study did not find an activation of PPAR $\alpha$ (Sun et al., 2007), whereas another reported $\Delta^{9}$-THC-induced transcriptional activity of PPAR $\alpha$ in breast cancer cells (Takeda et al., 2014). In line with this, cannabinoids such as WIN 55,212-2, AEA, OEA, virodhamine and noladin ether were revealed as PPAR $\alpha$ agonists in reporter gene assays (Sun et al., 2007). As a further cannabinoid target among the PPARs, PPAR $\gamma$ was shown to be activated by $\Delta^{9}$-THC (O'Sullivan et al., 2005, 2006), CBD (O'Sullivan et al., 2009) and AEA (Bouaboula et al., 2005).
Several lines of evidence suggest a possible contribution of PPARs to the anticarcinogenic effects of cannabinoids. Accordingly, $\Delta^{9}$-THC was found to exert antiproliferative effects on hepatocellular carcinoma cells in vitro and in vivo via PPAR $\gamma$ (Vara et al., 2013). Similar results were reported for WIN 55,2122 in hepatocarcinoma cells (Giuliano et al., 2009; Pellerito et al., 2010; Hong et al., 2013). Another study revealed an indirect action of cannabinoids on PPAR $\gamma$ activation. Thus, CBD and $\mathrm{R}(+)$-methanandamide were found to confer PPAR $\gamma$ activation via upregulation of COX-2 expression and subsequent release of prostaglandins, acting as PPAR $\gamma$ ligands (Eichele et al., 2009; Ramer et al., 2013).

\section{OTHER RECEPTOR TARGETS}

Accumulating evidence suggests glycine receptors as targets of phytocannabinoid action in context with their anti-inflammatory and antinociceptive properties. Accordingly, $\Delta^{9}$-THC and AEA were described to potentiate glycine currents in native neurons, hippocampus, amygdala, and spinal cord (Hejazi et al., 2006). A recent publication further unraveled the voltage-dependent anion channel 1 (VDAC1) as a mitochondrial receptor target of cannabinoids. Thus, microglial cell death was reported to occur through the inhibition of VDAC1 conductance by CBD (Rimmerman et al., 2013). The authors hypothesized that the inhibition of this channel may also be responsible for the anticancer properties of CBD.

\section{BIOSYNTHESIZING ENZYMES}

The biosynthesis of AEA and other $N$-ethanolamines is based on the transacylation-phosphodiesterase pathway (Schmid, 2000; Wang and Ueda, 2009), which consists of a first step, $\mathrm{N}$-acylation of phosphatidylethanolamine by $\mathrm{N}$-acyltransferases (Jin et al., 2007; Wang and Ueda, 2009). Subsequently a second step reaction of $N$-acyl-phosphatidylethanolamineselective phospholipase D (NAPE-PLD) generates AEA. Alternative sequential steps include the action of ABHD4 followed by turnover of the intermediate glycero-phosphatidylAEA via glycerophosphodiesterase 1. Another alternative pathway includes conversion of phosphatidylethanolamine via soluble phospholipase $\mathrm{A}_{2} \quad\left(\mathrm{sLA}_{2}\right)$ and subsequent turnover by lysophospholipase D (lyso-PLD). Finally, a third alternative metabolic pathway runs via phospholipase C (PLC) and downstream phosphatases such as PTPN22 and phosphatidylinositol 3,4,5-trisphosphate 5-phosphatase 1 (SHIP1) (Liu J. et al., 2008).

The biosynthesis of 2-AG is based on cleavage of membrane phospholipids via phospholipase $\mathrm{C}$ and by diacylglycerol (DAG) turnover via DAG lipase a and -b (Prescott and Majerus, 1983; Stella et al., 1997). Alternative pathways include combined action of phospholipase $\mathrm{A}_{1}\left(\mathrm{PLA}_{1}\right)$ and lyso-PLC (Sugiura et al., 1995) or dephosphorylation of arachidonic acid-containing lysophosphatidic acid (Nakane et al., 2002).

Concerning the regulation of endocannabinoidbiosynthesizing enzymes in cancer tissue, currently available 
data are rare. One investigation reported NAPE-PLD to appear to be downregulated in expression and activity level in glioma tissue, whereas the expression of DAGL remained unchanged (Wu et al., 2012). Notably, this disequilibrium, combined with a downregulation of both degrading enzymes, FAAH and MAGL, resulted in decreased AEA and increased 2-AG concentrations. In another study, however, NAPE-PLD mRNA was found to be upregulated in colorectal cancer tissue (Chen et al., 2015).

\section{DEGRADATION ENZYMES}

The main enzymes for endocannabinoid degradation are FAAH and MAGL. FAAH was first defined as the catabolic enzyme for AEA (Deutsch and Chin, 1993) and 2-AG (Di Marzo et al., 1998; Goparaju et al., 1999) and later also for the turnover of other fatty acid derivates such as the endocannabinoid-like substances OA (Cravatt et al., 1996), OEA and PEA (Desarnaud et al., 1995; Saghatelian et al., 2004). The major enzyme of 2-AG hydrolysis is MAGL (Blankman et al., 2007), although other enzymes such as ABHD6 and ABHD12 have also been demonstrated to hydrolyze 2-AG (Blankman et al., 2007). Furthermore, AEA and 2-AG are substrates for oxidation by COX-2, which subsequently results in prostaglandin ethanolamides and prostaglandin glycerol esters (Yu et al., 1997; Kalgutkar et al., 1999; Kozak et al., 2000). Another enzyme degrading AEA, OEA, and PEA is the lysosomal hydrolase $N$-acylethanolaminehydrolyzing acid amidase (NAAA) (Ueda et al., 1999; Sun et al., 2005). In particular, it has been suggested that NAAA plays a role in prostate carcinoma proliferation, as high expression in prostate carcinoma cells has been demonstrated (Wang J. et al., 2008). In agreement with this notion, one study found $N$-cyclohexanecarbonylpentadecylamine, an inhibitor of NAAA, to elicit decreased viability of neuroblastoma cells (Hamtiaux et al., 2011). A recent study aiming at the design of new NAAA inhibitors reported these NAAA inhibitors to induce bladder cancer cell death and reduce cell migration (Vago et al., 2017).

A number of studies suggest the main enzymes for endocannabinoid turnover, FAAH and MAGL, to appear upregulated in malignant tissue. Accordingly, higher expression levels of FAAH have been found in prostate cancer tissue (Endsley et al., 2008). In addition, a correlation between high FAAH expression and disease severity has been identified (Thors et al., 2010). Increases in MAGL expression were observed in ovarian tumors, in colorectal cancer tissues (Nomura et al., 2010; Ye et al., 2011; Pagano et al., 2017) and in ductal breast tumors compared to less malignant breast tumors (Gjerstorff et al., 2006). Such association was further confirmed for colon tumor cases, where the prognosis for patients with high MAGL expression was markedly poorer than that for those with low MAGL expression (Zhu et al., 2016). In contrast to these findings, high levels of FAAH and MAGL correlate with a positive survival prognosis for patients with pancreatic ductal adenocarcinomas (Michalski et al., 2008). In terms of endometrial carcinoma, another study presented downregulation of MAGL in cancer versus healthy tissue (Guida et al., 2010) which was later confirmed for colorectal, lung, breast, stomach and ovarian cancers (Sun et al., 2013). Notably, these findings support the notion of the endocannabinoid-degrading enzymes being tumor suppressors rather than tumor promoters.

During the last two decades endocannabinoid-degrading enzymes have attracted considerable interest as probable targets of an innovative anticancer treatment. Thus, inhibitors of FAAH such as AA-5HT, which cause reduction of AEA turnover and prolonged action of AEA at cannabinoid receptors, were found to be potent inhibitors of glioma (Jacobsson et al., 2001), colorectal (Ligresti et al., 2003) and thyroid cancer cell proliferation (Bifulco et al., 2004). AA-5HT was further proven to reduce aberrant crypt foci in a murine colon carcinogenesis model (Izzo et al., 2008). URB597, another FAAH inhibitor, was shown to reduce proliferation of neuroblastoma cells when combined with the FAAH substrate AEA (Hamtiaux et al., 2011). Similar results were obtained from experiments in which URB597 was combined with Met-F-AEA on colorectal (Proto et al., 2012) and lung cancer cells (Hamtiaux et al., 2012), with the latter study further demonstrating an antiproliferative impact of combined treatment with URB597 and PEA on melanoma cells. In addition to antiproliferative properties, the FAAH inhibitor CAY10401 decreased prostate cancer cell invasion (Endsley et al., 2008). URB597 and AA-5HT were further found to decrease human lung cancer cell invasion via $\mathrm{CB}_{2}$ - and TRPV1-dependent upregulation of TIMP-1 (Winkler et al., 2016). An involvement of $\mathrm{CB}_{1}$ in the antiproliferative action on colorectal carcinoma cells was proven for AA-5HT (Ligresti et al., 2003).

In agreement with the proposed inhibitory impact of 2-AG on cancer progression, the MAGL inhibitor JZL184 was found to elicit antiproliferative and proapoptotic effects on colorectal cancer cells (Ye et al., 2011). Concerning effects on cancer cell invasion, JZL184 was also reported to exert inhibitory action on prostate carcinoma cells in vitro and in vivo (Nomura et al., 2011a). A contribution of the cannabinoid receptors in this context is under controversial discussion. On the one hand, a partial involvement of $\mathrm{CB}_{1}$ in the anti-invasive and growth-inhibitory impact of MAGL inhibition has been reported (Nomura et al., 2011a). On the other hand, the anticarcinogenic features of different cancer cells were shown to be rescued by add-back of free fatty acids in vitro and by a high-fat diet in vivo (Nomura et al., 2010). These findings are in line with a report, which presented MAGL activity as a source of arachidonic precursors that cause inflammation (Nomura et al., 2011b). In another study, JZL184 was found to inhibit proliferation of prostate cancer cells exclusively when these were activated with EGF (Cipriano et al., 2014). Other MAGL inhibitors that were proven to exert anticancer properties are the reversible MAGL inhibitor pristimerin, which elicited cancer cell apoptosis (Yousef et al., 2017), and URB602, which caused inhibition of tumor angiogenesis via downregulation of vascular endothelial growth factor (VEGF) and fibroblast growth factor (Pagano et al., 2017).

\section{TRANSPORT PROTEINS}

As intracellular transporters that coordinate the delivery of AEA and 2-AG, as well as of OEA and PEA, to their 
catabolic enzymes, members of the fatty acid-binding protein (FABP) family have been the matter of debate in recent years. Furthermore, FABPs were discussed as proteins that shuttle between cytosol and nucleus and thereby deliver endocannabinoid compounds to their intracellular targets such as PPARs. In particular, FABP inhibitors have raised scientific interest as a treatment option for analgesic and antiinflammatory purposes (Kaczocha et al., 2014).

Currently, 10 FABP subtypes with tissue-specific distributions are known (for review, see Thumser et al., 2014). For several FABPs, the binding capacities of endocannabinoids and endocannabinoid-like substances have been reported (Kaczocha et al., 2009, 2012; Sanson et al., 2014; Huang et al., 2016). In this context, a gender-specific endocannabinoid regulation was elucidated for FABP1. Accordingly, brains of male FABP1 knockout mice were shown to content higher concentrations of AEA, 2-AG, OEA, and PEA compared to wild-type mice (Martin et al., 2016b). In contrast to this, another study from the same group was able to demonstrate that AEA and 2-AG levels were unaltered and OEA and PEA were decreased in brains of female FABP1 knockout mice as compared to wild-type animals (Martin et al., 2016a). In addition, $\Delta^{9}$-THC and $\Delta^{9}-\mathrm{THC}-\mathrm{OH}$, as well as downstream metabolites of $\Delta^{9}$-THC such as $\Delta^{9}$-THC-COOH and $\Delta^{9}$-THC-CO-glucuronide were found as binding partners of hepatic FABP1 (Huang et al., 2018). Furthermore, a potentiated uptake of AEA was described for FABP5-overexpressing neuroblastoma cells (Kaczocha et al., 2009). In FABP5 and FABP7 knockout mice, upregulation of AEA, PEA and OEA have been linked to reduced nociception, with the antinociceptive action being sensitive to antagonists to $\mathrm{CB}_{1}$, PPAR $\alpha$ and TRPV1 (Kaczocha et al., 2015). For the endocannabinoid-like substance OEA, one investigation supported the notion of FABP5 as an intracellular shuttling protein that mediates activation of PPAR $\alpha$ (Kaczocha et al., 2012).

As reviewed previously (Schwarz et al., 2018), a number of FABPs are involved in carcinogenesis. Thus, FABP1 has been found to increase tumor angiogenesis in hepatocarcinoma by upregulation of VEGF (Ku et al., 2016), and FABP4 was shown to enhance cancer aggressiveness in different tumor entities such as myeloid leukemia (Yan et al., 2017), prostate (Herroon et al., 2013; Uehara et al., 2014) and breast cancer (Guaita-Esteruelas et al., 2017). FABP5 knockdown was shown to inhibit tumor cell proliferation and invasiveness of cervical cancer cells (Wang W. et al., 2016) and oral squamous cell carcinoma (Fang et al., 2010) as well as tumor cell proliferation of prostate cancer cells (Kawaguchi et al., 2016). In agreement with these findings, inhibition of FABP5 was associated with reduced carcinogenic potential of mammary carcinoma (Kannan-Thulasiraman et al., 2010; Levi et al., 2013; Zhang et al., 2015) and prostate cancer cells (Forootan et al., 2014). A recent investigation reported upregulation of VEGF in response to a FABP5dependent activation of PPAR $\gamma$ as a crucial event in tumor neovascularization of prostate cancers (Forootan et al., 2016). Furthermore, increase of tumor cell migration was found to be associated with FABP7 overexpression (Mita et al., 2010).

The association of enhanced carcinogenesis and FABP overexpression, however, is not uniformly confirmed by other studies. Accordingly, binding of FABP3 to the integrin $\alpha$-subunit was found to be associated with inhibition of breast cancer cell invasion (Nevo et al., 2010). FABP3 overexpression was furthermore reported to confer apoptosis in a teratocarcinoma cell line (Song et al., 2012). In addition, FABP7 was significantly upregulated, whereas FABP1 appeared downregulated in renal cell carcinoma as compared to normal tissue (Tölle et al., 2009). Downregulation of FABP1 was correlated with tumor differentiation and intratumoral inflammation (Inoue et al., 2014). Finally, the high expression of FABP1 in hepatocellular carcinoma was associated with a better prognosis than in patients with low FABP1 expression (Wang et al., 2014).

Although data concerning anticancer effects of FABP inhibitors acting via endocannabinoids are still missing, some investigations reported that FABP inhibitors actually developed for the treatment of obesity, atherosclerosis, diabetes, and metabolic syndrome (for review, see Wang Y.T et al., 2016) modulate the endocannabinoid system. Therefore, these FABP inhibitors could perhaps serve as potential tools to inhibit cancer progression. BMS309403, designed as an FABP4 inhibitor that also elicits its effects on HeLa cells that dominantly express FABP5 (Kaczocha et al., 2012), was shown to increase AEA in neuroblastoma cells (Kaczocha et al., 2009). Furthermore, SB-FI26, an FABP5 inhibitor, was likewise found to increase AEA in rat sarcoma cells (Björklund et al., 2014).

\section{CLINICAL IMPLICATION AND OUTLOOK}

Taking into account the different facts concerning cannabinoid action on cancer cells and tissue in vitro and in vivo, the endocannabinoid system encompasses several attractive pharmacotherapeutic targets for cancer treatment.

Currently, cannabinoids are used for palliative treatment of cancer patients. In this context, a recent meta-analysis included nine randomized controlled and crossover trials of palliative care using cannabinoid compounds and reported only low-quality evidence of a clinical benefit of cannabinoids in the treatment of cancer pain and overall no recommendations for the use of cannabinoids in palliative care treatment for cancer (Mücke et al., 2018). Another meta-analysis reported a reduction of at least $30 \%$ in chronic pain of diverse origins with cannabinoids compared to the placebo group. The authors stated moderate-quality evidence for cannabinoids (smoked $\Delta^{9}$-THC and nabiximols, an approximate 1:1 combination of $\Delta^{9}$-THC and CBD) as beneficial for the treatment of chronic neuropathic or cancer pain and lowquality evidence for the cannabinoids dronabinol and nabiximols as beneficial treatment options for chemotherapy-induced nausea and vomiting (Whiting et al., 2015). Thus, the efficacy of cannabinoid-based drugs in the treatment of these classical symptoms of cancer and cancer treatment has to be evaluated critically. However, besides reduction of chemotherapeuticinduced emesis, nausea and pain, cannabinoids may also reduce other severe side effects caused by currently used cytostatics. Accordingly, a recent study revealed cannabinoids as possible treatment options against cisplatin-induced traumatic cochlear insult (Ghosh et al., 2018). Cisplatin-induced nephrotoxicity 
is another adverse effect that may be counteracted by CBD (Pan et al., 2009) and the peripherally restricted cannabinoid $\mathrm{CB}_{2}$ receptor agonist LEI-101 (Mukhopadhyay et al., 2016) as has been proven in a rodent model. Furthermore, doxorubicininduced cardiotoxicity has recently been shown to be suppressed by the cannabinoid WIN55,212-2 in mice (Rahmatollahi et al., 2016). Several studies further reported cannabinoids to reduce peripheral neuropathy in the context of HIV infections (Andreae et al., 2015) and diabetes (Wallace et al., 2015), thereby suggesting further use in the prevention of chemotherapeutic-induced neuropathy, as has been discussed recently (Abrams, 2016).

Concerning systemic effects of cannabinoids to combat disease severities of cancer, recently published orphan drug designations for cannabinoids as a treatment option for glioma pave the way for clinical evaluations of cannabinoids in cancer treatment. Accordingly, in the USA CBD (FDA, 2014) and a combination of $\Delta^{9}$-THC and CBD (FDA, 2015, 2018) have received orphan drug designations, while in Europe an orphan drug designation was granted only for the combination of $\Delta^{9}$-THC and CBD (EMA, 2016). One probable advantage for cancer patients in this context may lie in the broad array of anticancer effects of cannabinoids, which include inhibitory effects on cancer cell proliferation, angiogenesis, invasion and chemoresistance, while inducing apoptosis, autophagy and tumor immune surveillance. Particularly the latter effect has been discussed controversially in recent years. On the one hand, $\Delta^{9}$-THC was found to cause enhanced tumor growth in immunocompetent murine tumor models in terms of lung and breast cancer xenografts (Zhu et al., 2000; McKallip et al., 2005). On the other hand, using a melanoma xenograft model WIN55,212-2 exerted the opposite effects. Accordingly, the tumor-regressive action of WIN55,212-2 was more pronounced in immunocompetent than in immunodeficient mice (Blázquez et al., 2006). Another study further found reduction of breast cancer growth and metastasis in an immunocompetent mouse model in response to treatment with the $\mathrm{CB}_{2}$ receptor agonist JWH-015 (Hanlon et al., 2016). Concerning the mechanisms leading to enhancement of tumor-immune interactions, a recent study found an increase of tumor cell killing via lymphokineactivated killer cells crosslinked by LFA-1 to CBD-, $\Delta^{9}$ THC- and R(+)-methanandamide-induced ICAM-1 on the surface of lung cancer cells (Haustein et al., 2014). Finally,

\section{REFERENCES}

Abrams, D. I. (2016). Integrating cannabis into clinical cancer care. Curr. Oncol. 23, S8-S14. doi: 10.3747/co.23.3099

Adinolfi, B., Romanini, A., Vanni, A., Martinotti, E., Chicca, A., Fogli, S., et al. (2013). Anticancer activity of anandamide in human cutaneous melanoma cells. Eur. J. Pharmacol. 718, 154-159. doi: 10.1016/j.ejphar.2013. 08.039

Akimov, M. G., Ashba, A. M., Gretskaya, N. M., and Bezuglov, V. V. (2017). N-Acyl dopamines induce apoptosis in PC12 cell line via the GPR55 receptor activation. Dokl. Biochem. Biophys. 474, 155-158. doi: 10.1134/S1607672917030012

Akimov, M. G., Gretskaya, N. M., Zinchenko, G. N., and Bezuglov, V. V. (2015). Cytotoxicity of endogenous lipids $\mathrm{N}$-acyl dopamines and their possible metabolic derivatives for human cancer cell lines of different histological origin. Anticancer Res. 35, 2657-2661. one study reported reduced infiltration of macrophages and neutrophils in cancer tissue of animals treated with $\Delta^{9}$-THC (Glodde et al., 2015).

However, the efficacy of these drugs will have to be thoroughly evaluated in clinical studies. Notably, a recent publication presented a collection of clinical cases of cancer patients who had received synthetic, pharmaceutical-grade CBD, with several cases exhibiting reduction in cancer size or in the number of circulating cancer cells (Kenyon et al., 2018). However, clinical studies with the respective control groups have to be conducted to define clearly the systemic anticancer effects, particularly with respect to efficient doses. So far the scientific literature provides merely a single pilot study that addressed the safety of intracranially administered $\Delta^{9}$-THC in patients suffering from glioblastoma multiforme. Due to the design and the size of the clinical trial that enrolled nine patients with recurrent glioblastoma multiforme, a conclusion concerning the effect of $\Delta^{9}$-THC on patients' survival cannot be drawn (Guzman et al., 2006).

One important factor that further argues for the use of cannabinoid-based drugs in cancer therapy may lie in their synergistic action on the efficacy of currently used chemotherapeutic drugs. Particularly, $\Delta^{9}$-THC and CBD were found to synergistically act on anticarcinogenic properties of bortezomib (Morelli et al., 2014), carfilzomib (Nabissi et al., 2016), carmustine (Nabissi et al., 2013), cisplatin (Deng et al., 2017), cytarabine (Liu W. M. et al., 2008), doxorubicin (Liu W. M. et al., 2008; Nabissi et al., 2013; Elbaz et al., 2016), mitoxantrone (Holland et al., 2007), temozolomide (Torres et al., 2011; Nabissi et al., 2013; López-Valero et al., 2018), and vinca alkaloids (Holland et al., 2006; Liu W. M. et al., 2008).

Taken together, cannabinoids and compounds affecting the endocannabinoid system may complement the range of currently used chemotherapeutic agents as a pharmacotherapeutic option for cancer treatment with broadly diversified mechanisms.

\section{AUTHOR CONTRIBUTIONS}

RR wrote the manuscript in consultation with and under input of RS and $\mathrm{BH}$. All authors discussed the manuscript, table and figure and commented on the manuscript. $\mathrm{BH}$ supervised the manuscript.

Andreae, M. H., Carter, G. M., Shaparin, N., Suslov, K., Ellis, R. J., Ware, M. A., et al. (2015). Inhaled cannabis for chronic neuropathic pain: a meta-analysis of individual patient data. J. Pain 16, 1221-1232. doi: 10.1016/j.jpain.2015. 07.009

Artmann, A., Petersen, G., Hellgren, L. I., Boberg, J., Skonberg, C., Nellemann, C., et al. (2008). Influence of dietary fatty acids on endocannabinoid and $\mathrm{N}$-acylethanolamine levels in rat brain, liver and small intestine. Biochim. Biophys. Acta 1781, 200-212. doi: 10.1016/j.bbalip.2008.01.006

Aviello, G., Romano, B., Borrelli, F., Capasso, R., Gallo, L., Piscitelli, F., et al. (2012). Chemopreventive effect of the non-psychotropic phytocannabinoid cannabidiol on experimental colon cancer. J. Mol. Med. (Berl.) 90, 925-934. doi: 10.1007/s00109-011-0856-x

Bifulco, M., Laezza, C., Portella, G., Vitale, M., Orlando, P., De Petrocellis, L., et al. (2001). Control by the endogenous cannabinoid system of ras oncogenedependent tumor growth. FASEB J. 15, 2745-2747. 
Bifulco, M., Laezza, C., Valenti, M., Ligresti, A., Portella, G., and Di Marzo, V. (2004). A new strategy to block tumor growth by inhibiting endocannabinoid inactivation. FASEB J. 18, 1606-1608.

Bisogno, T., Hanus, L., De Petrocellis, L., Tchilibon, S., Ponde, D. E., Brandi, I., et al. (2001). Molecular targets for cannabidiol and its synthetic analogues: effect on vanilloid VR1 receptors and on the cellular uptake and enzymatic hydrolysis of anandamide. Br. J. Pharmacol. 134, 845-852.

Bisogno, T., Katayama, K., Melck, D., Ueda, N., De Petrocellis, L., Yamamoto, S., et al. (1998). Biosynthesis and degradation of bioactive fatty acid amides in human breast cancer and rat pheochromocytoma cells - Implications for cell proliferation and differentiation. Eur. J. Biochem. 254, 634-642.

Bisogno, T., Melck, D., Bobrov, M. Yu., Gretskaya, N. M., Bezuglov, V. V., De Petrocellis, L., et al. (2000). N-Acyl-dopamines: novel synthetic CB(1) cannabinoid-receptor ligands and inhibitors of anandamide inactivation with cannabimimetic activity in vitro and in vivo. Biochem. J. 351, 817-824.

Björklund, E., Blomqvist, A., Hedlin, J., Persson, E., and Fowler, C. J. (2014). Involvement of fatty acid amide hydrolase and fatty acid binding protein 5 in the uptake of anandamide by cell lines with different levels of fatty acid amide hydrolase expression: a pharmacological study. PLoS One 9:e103479. doi: 10.1371/journal.pone.0103479

Blankman, J. L., Simon, G. M., and Cravatt, B. F. (2007). A comprehensive profile of brain enzymes that hydrolyze the endocannabinoid 2-arachidonoylglycerol. Chem. Biol. 14, 1347-1356.

Blázquez, C., Carracedo, A., Barrado, L., Real, P. J., Fernández-Luna, J. L., Velasco, G., et al. (2006). Cannabinoid receptors as novel targets for the treatment of melanoma. FASEB J. 20, 2633-2635.

Borrelli, F., Pagano, E., Romano, B., Panzera, S., Maiello, F., Coppola, D., et al. (2014). Colon carcinogenesis is inhibited by the TRPM8 antagonist cannabigerol, a cannabis-derived non-psychotropic cannabinoid. Carcinogenesis 35, 2787-2797. doi: 10.1093/carcin/bgu205

Bouaboula, M., Hilairet, S., Marchand, J., Fajas, L., Le Fur, G., and Casellas, P. (2005). Anandamide induced PPARgamma transcriptional activation and 3T3-L1 preadipocyte differentiation. Eur. J. Pharmacol. 517, 174-181.

Brantl, S. A., Khandoga, A. L., and Siess, W. (2014). Mechanism of platelet activation induced by endocannabinoids in blood and plasma. Platelets 25, 151-161. doi: 10.3109/09537104.2013.803530

Brown, I., Cascio, M. G., Wahle, K. W., Smoum, R., Mechoulam, R., Ross, R. A., et al. (2010). Cannabinoid receptor-dependent and -independent antiproliferative effects of omega-3 ethanolamides in androgen receptor-positive and -negative prostate cancer cell lines. Carcinogenesis 31, 1584-1591. doi: 10.1093/carcin/bgq151

Brown, K. J., Laun, A. S., and Song, Z. H. (2017). Cannabidiol, a novel inverse agonist for GPR12. Biochem. Biophys. Res. Commun. 493, 451-454. doi: 10. 1016/j.bbrc.2017.09.001

Calatozzolo, C., Salmaggi, A., Pollo, B., Sciacca, F. L., Lorenzetti, M., Franzini, A., et al. (2007). Expression of cannabinoid receptors and neurotrophins in human gliomas. Neurol. Sci. 28, 304-310. doi: 10.1007/s10072-007-0843-8

Chen, L., Chen, H., Li, Y., Li, L., Qiu, Y., and Ren, J. (2015). Endocannabinoid and ceramide levels are altered in patients with colorectal cancer. Oncol. Rep. 34, 447-454. doi: 10.3892/or.2015.3973

Chung, S. C., Hammarsten, P., Josefsson, A., Stattin, P., Granfors, T., Egevad, L., et al. (2009). A high cannabinoid $\mathrm{CB}(1)$ receptor immunoreactivity is associated with disease severity and outcome in prostate cancer. Eur. J. Cancer 45, 174-182. doi: 10.1016/j.ejca.2008.10.010

Cipriano, M., Gouveia-Figueira, S., Persson, E., Nording, M., and Fowler, C. J. (2014). The influence of monoacylglycerol lipase inhibition upon the expression of epidermal growth factor receptor in human PC-3 prostate cancer cells. BMC Res. Notes 7:441. doi: 10.1186/1756-0500-7-441

Contassot, E., Tenan, M., Schnüriger, V., Pelte, M. F., and Dietrich, P. Y. (2004). Arachidonyl ethanolamide induces apoptosis of uterine cervix cancer cells via aberrantly expressed vanilloid receptor-1. Gynecol. Oncol. 93, 182-188.

Cravatt, B. F., Giang, D. K., Mayfield, S. P., Boger, D. L., Lerner, R. A., and Gilula, N. B. (1996). Molecular characterization of an enzyme that degrades neuromodulatory fatty-acid amides. Nature 384, 83-87.

Czifra, G., Varga, A., Nyeste, K., Marincsák, R., Tóth, B. I., Kovács, I., et al. (2009). Increased expressions of cannabinoid receptor-1 and transient receptor potential vanilloid-1 in human prostate carcinoma. J. Cancer Res. Clin. Oncol. 135, 507-514. doi: 10.1007/s00432-008-0482-3
Das, S. K., Paria, B. C., Chakraborty, I., and Dey, S. K. (1995). Cannabinoid ligand-receptor signaling in the mouse uterus. Proc. Natl. Acad. Sci. U.S.A. 92, 4332-4336.

Davies, J. W., Hainsworth, A. H., Guerin, C. J., and Lambert, D. G. (2010). Pharmacology of capsaicin-, anandamide-, and N-arachidonoyl-dopamineevoked cell death in a homogeneous transient receptor potential vanilloid subtype 1 receptor population. Br. J. Anaesth. 104, 596-602. doi: 10.1093/bja/ aeq067

De Petrocellis, L., Bisogno, T., Ligresti, A., Bifulco, M., Melck, D., and Di Marzo, V. (2002). Effect on cancer cell proliferation of palmitoylethanolamide, a fatty acid amide interacting with both the cannabinoid and vanilloid signalling systems. Fundam. Clin. Pharmacol. 16, 297-302.

De Petrocellis, L., Ligresti, A., Moriello, A. S., Allarà, M., Bisogno, T., Petrosino, S., et al. (2011). Effects of cannabinoids and cannabinoid-enriched Cannabis extracts on TRP channels and endocannabinoid metabolic enzymes. Br. J. Pharmacol. 163, 1479-1494. doi: 10.1111/j.1476-5381.2010.01166.x

De Petrocellis, L., Melck, D., Palmisano, A., Bisogno, T., Laezza, C., Bifulco, M., et al. (1998). The endogenous cannabinoid anandamide inhibits human breast cancer cell proliferation. Proc. Natl. Acad. Sci. U.S.A. 95, 8375-8380.

De Petrocellis, L., Orlando, P., Moriello, A. S., Aviello, G., Stott, C., Izzo, A. A., et al. (2012). Cannabinoid actions at TRPV channels: effects on TRPV3 and TRPV4 and their potential relevance to gastrointestinal inflammation. Acta Physiol. (Oxf.) 204, 255-266. doi: 10.1111/j.1748-1716.2011.02338.x

De Petrocellis, L., Vellani, V., Schiano-Moriello, A., Marini, P., Magherini, P. C., Orlando, P., et al. (2008). Plant-derived cannabinoids modulate the activity of transient receptor potential channels of ankyrin type-1 and melastatin type-8. J. Pharmacol. Exp. Ther. 325, 1007-1015. doi: 10.1124/jpet.107. 134809

Deng, L., Ng, L., Ozawa, T., and Stella, N. (2017). Quantitative analyses of synergistic responses between cannabidiol and DNA-damaging agents on the proliferation and viability of glioblastoma and neural progenitor cells in culture. J. Pharmacol. Exp. Ther. 360, 215-224. doi: 10.1124/jpet.116.236968

Desarnaud, F., Cadas, H., and Piomelli, D. (1995). Anandamide amidohydrolase activity in rat brain microsomes. Identification and partial characterization. J. Biol. Chem. 270, 6030-6035.

Deutsch, D. G., and Chin, S. A. (1993). Enzymatic synthesis and degradation of anandamide, a cannabinoid receptor agonist. Biochem. Pharmacol. 46, 791-796.

Devane, W. A., Hanus, L., Breuer, A., Pertwee, R. G., Stevenson, L. A., Griffin, G., et al. (1992). Isolation and structure of a brain constituent that binds to the cannabinoid receptor. Science 258, 1946-1949.

Di Marzo, V. (2009). The endocannabinoid system: its general strategy of action, tools for its pharmacological manipulation and potential therapeutic exploitation. Pharmacol. Res. 60, 77-84. doi: 10.1016/j.phrs.2009.02.010

Di Marzo, V., Bisogno, T., Sugiura, T., Melck, D., and De Petrocellis, L. (1998). The novel endogenous cannabinoid 2-arachidonoylglycerol is inactivated by neuronal- and basophil-like cells: connections with anandamide. Biochem. J. $331,15-19$.

Di Marzo, V., and De Petrocellis, L. (2012). Why do cannabinoid receptors have more than one endogenous ligand? Philos. Trans. R. Soc. Lond. B Biol. Sci. 367, 3216-3228. doi: 10.1098/rstb.2011.0382

Di Marzo, V., De Petrocellis, L., Fezza, F., Ligresti, A., and Bisogno, T. (2002). Anandamide receptors, prostaglandins leukot. Essent. Fatty Acids 66, 377-391.

Di Marzo, V., Melck, D., Orlando, P., Bisogno, T., Zagoory, O., Bifulco, M., et al. (2001). Palmitoylethanolamide inhibits the expression of fatty acid amide hydrolase and enhances the anti-proliferative effect of anandamide in human breast cancer cells. Biochem. J. 358, 249-255.

Duncan, M., Millns, P., Smart, D., Wright, J. E., Kendall, D. A., and Ralevic, V. (2004). Noladin ether, a putative endocannabinoid, attenuates sensory neurotransmission in the rat isolated mesenteric arterial bed via a nonCB1/CB2 G(i/o) linked receptor. Br. J. Pharmacol. 142, 509-518.

Eichele, K., Ramer, R., and Hinz, B. (2009). R(+)-methanandamide-induced apoptosis of human cervical carcinoma cells involves a cyclooxygenase2-dependent pathway. Pharm. Res. 26, 346-355. doi: 10.1007/s11095-0089748-3

Eichele, K., Weinzierl, U., Ramer, R., Brune, K., and Hinz, B. (2006). $\mathrm{R}(+)$-methanandamide elicits a cyclooxygenase-2-dependent mitochondrial apoptosis signaling pathway in human neuroglioma cells. Pharm. Res. 23, 90-94. 
Elbaz, M., Ahirwar, D., Xiaoli, Z., Zhou, X., Lustberg, M., Nasser, M. W., et al. (2016). TRPV2 is a novel biomarker and therapeutic target in triple negative breast cancer. Oncotarget 9, 33459-33470. doi: 10.18632/oncotarget.9663

EMA (2016). Committee for Orphan Medicinal Products, Public Summary of Opinion on Orphan Designation. Delta-9-Tetrahydrocannabinol and Cannabidiol from extracts of the Cannabis sativa L. Plant for the Treatment glioma. Orphan Drug Designation-Number: EU/3/16/1621European Medicines Agency. Available at: https://www.ema.europa.eu/documents/orphandesignation/eu/3/16/1621-public-summary-opinion-orphan-designationdelta-9-tetrahydrocannabinol-cannabidiol-extracts_en.pdf (accessed December 18, 2018).

Endsley, M. P., Thill, R., Choudhry, I., Williams, C. L., Kajdacsy-Balla, A., Campbell, W. B., et al. (2008). Expression and function of fatty acid amide hydrolase in prostate cancer. Int. J. Cancer 123, 1318-1326. doi: 10.1002/ijc. 23674

Fang, L. Y., Wong, T. Y., Chiang, W. F., and Chen, Y. L. (2010). Fatty-acid binding protein 5 promotes cell proliferation and invasion in oral squamous cell carcinoma. J. Oral. Pathol. Med. 39, 342-348. doi: 10.1111/j.1600-0714.2009. 00836.x

FDA (2014). Orphan Drug Designations and Approvals. Treatment of glioblastoma multiforme.Available at: https://www.accessdata.fda.gov/scripts/opdlisting/ oopd/listResult.cfm (accessed December 19, 2018).

FDA (2015). FDA Internet Application Site. Available at: https://www.accessdata. fda.gov/scripts/opdlisting/oopd/detailedIndex.cfm?cfgridkey (450814); https:// www.accessdata.fda.gov/scripts/opdlisting/oopd/detailedIndex.cfm?cfgridkey (498215) (accessed December 19, 2018).

FDA (2018). Orphan Drug Designations and Approvals. Available at: https:// www.accessdata.fda.gov/scripts/opdlisting/oopd/detailedIndex.cfm?cfgridkey (620417) (accessed December 19, 2018).

Finlay, D. B., Joseph, W. R., Grimsey, N. L., and Glass, M. (2016). GPR18 undergoes a high degree of constitutive trafficking but is unresponsive to $\mathrm{N}$-arachidonoyl glycine. PeerJ 4:e1835. doi: 10.7717/peerj.1835

Fonseca, B. M., Correia-da-Silva, G., and Teixeira, N. A. (2018). Cannabinoidinduced cell death in endometrial cancer cells: involvement of TRPV1 receptors in apoptosis. J. Physiol. Biochem. 74, 261-272. doi: 10.1007/s13105-0180611-7

Forootan, F. S., Forootan, S. S., Gou, X., Yang, J., Liu, B., Chen, D., et al. (2016). Fatty acid activated PPAR $\gamma$ promotes tumorigenicity of prostate cancer cells by up regulating VEGF via PPAR responsive elements of the promoter. Oncotarget 7, 9322-9339.

Forootan, F. S., Forootan, S. S., Malki, M. I., Chen, D., Li, G., Lin, K., et al. (2014). The expression of C-FABP and PPAR $\gamma$ and their prognostic significance in prostate cancer. Int. J. Oncol. 44, 265-275. doi: 10.3892/ijo.2013.2166

Fu, J., Gaetani, S., Oveisi, F., Lo Verme, J., Serrano, A., Rodríguez, et al. (2003). Oleylethanolamide regulates feeding and body weight through activation of the nuclear receptor PPAR-alpha. Nature 425, 90-93.

Ghosh, S., Sheth, S., Sheehan, K., Mukherjea, D., Dhukhwa, A., Borse, V., et al. (2018). The endocannabinoid/cannabinoid receptor 2 system protects against cisplatin-induced hearing loss. Front. Cell. Neurosci. 12:271. doi: 10.3389/fncel. 2018.00271

Giuliano, M., Pellerito, O., Portanova, P., Calvaruso, G., Santulli, A., De Blasio, A., et al. (2009). Apoptosis induced in HepG2 cells by the synthetic cannabinoid WIN: involvement of the transcription factor PPARgamma. Biochimie 91, 457-465. doi: 10.1016/j.biochi.2008.11.003

Gjerstorff, M. F., Benoit, V. M., Laenkholm, A. V., Nielsen, O., Johansen, L. E., and Ditzel, H. J. (2006). Identification of genes with altered expression in medullary breast cancer vs. ductal breast cancer and normal breast epithelia. Int. J. Oncol. 28, 1327-1335.

Glodde, N., Jakobs, M., Bald, T., Tüting, T., and Gaffal, E. (2015). Differential role of cannabinoids in the pathogenesis of skin cancer. Life Sci. 138, 35-40. doi: 10.1016/j.lfs.2015.04.003

Gonsiorek, W., Lunn, C., Fan, X., Narula, S., Lundell, D., and Hipkin, R. W. (2000). Endocannabinoid 2-arachidonyl glycerol is a full agonist through human type 2 cannabinoid receptor: antagonism by anandamide. Mol. Pharmacol. 57, 1045-1050.

Goparaju, S. K., Ueda, N., Taniguchi, K., and Yamamoto, S. (1999). Enzymes of porcine brain hydrolyzing 2-arachidonoylglycerol, an endogenous ligand of cannabinoid receptors. Biochem. Pharmacol. 57, 417-423.
Grimaldi, C., Pisanti, S., Laezza, C., Malfitano, A. M., Santoro, A., Vitale, M., et al. (2006). Anandamide inhibits adhesion and migration of breast cancer cells. Exp. Cell. Res. 312, 363-373.

Guaita-Esteruelas, S., Bosquet, A., Saavedra, P., Gumà, J., Girona, J., Lam, E. W., et al. (2017). Exogenous FABP4 increases breast cancer cell proliferation and activates the expression of fatty acid transport proteins. Mol. Carcinog. 56, 208-217. doi: 10.1002/mc.22485

Guida, M., Ligresti, A., De Filippis, D., D’Amico, A., Petrosino, S., Cipriano, M., et al. (2010). The levels of the endocannabinoid receptor CB2 and its ligand 2 -arachidonoylglycerol are elevated in endometrial carcinoma. Endocrinology 151, 921-928.

Gustafsson, K., Christensson, B., Sander, B., and Flygare, J. (2006). Cannabinoid receptor-mediated apoptosis induced by $\mathrm{R}(+)$-methanandamide and Win55,212-2 is associated with ceramide accumulation and p38 activation in mantle cell lymphoma. Mol. Pharmacol. 70, 1612-1620.

Guzman, M., Duarte, M. J., Blazquez, C., Ravina, J., Rosa, M. C., Galve-Roperh, I., et al. (2006). A pilot study of Delta9-tetrahydrocannabinol in patients with recurrent glioblastoma multiforme. Br. J. Cancer 95, 197-203.

Hamtiaux, L., Hansoulle, L., Dauguet, N., Muccioli, G. G., Gallez, B., and Lambert, D. M. (2011). Increasing antiproliferative properties of endocannabinoids in N1E-115 neuroblastoma cells through inhibition of their metabolism. PLoS One 6:e26823. doi: 10.1371/journal.pone.0026823

Hamtiaux, L., Masquelier, J., Muccioli, G. G., Bouzin, C., Feron, O., Gallez, B., et al. (2012). The association of N-palmitoylethanolamine with the FAAH inhibitor URB597 impairs melanoma growth through a supra-additive action. BMC Cancer 12:92. doi: 10.1186/1471-2407-12-92

Hanlon, K. E., Lozano-Ondoua, A. N., Umaretiya, P. J., Symons-Liguori, A. M., Chandramouli, A., Moy, J. K., et al. (2016). Modulation of breast cancer cell viability by a cannabinoid receptor 2 agonist, JWH-015, is calcium dependent. Breast Cancer (Dove Med Press) 8, 59-71. doi: 10.2147/BCTT.S100393

Hanus, L., Abu-Lafi, S., Fride, E., Breuer, A., Vogel, Z., Shalev, D. E., et al. (2001). 2-arachidonyl glyceryl ether, an endogenous agonist of the cannabinoid CB1 receptor. Proc. Natl. Acad. Sci. U.S.A. 98, 3662-3665.

Hasenoehrl, C., Feuersinger, D., Sturm, E. M., Bärnthaler, T., Heitzer, E., Graf, R., et al. (2018). G protein-coupled receptor GPR55 promotes colorectal cancer and has opposing effects to cannabinoid receptor 1. Int. J. Cancer 142, 121-132. doi: 10.1002/ijc.31030

Haustein, M., Ramer, R., Linnebacher, M., Manda, K., and Hinz, B. (2014). Cannabinoids increase lung cancer cell lysis by lymphokine-activated killer cells via upregulation of ICAM-1. Biochem. Pharmacol. 92, 312-325. doi: 10.1016/j. bcp.2014.07.014

Hejazi, N., Zhou, C., Oz, M., Sun, H., Ye, J. H., and Zhang, L. (2006). Delta9tetrahydrocannabinol and endogenous cannabinoid anandamide directly potentiate the function of glycine receptors. Mol. Pharmacol. 69, 991-997.

Henstridge, C. M., Balenga, N. A., Kargl, J., Andradas, C., Brown, A. J., Irving, A., et al. (2011). Minireview: recent developments in the physiology and pathology of the lysophosphatidylinositol-sensitive receptor GPR55. Mol. Endocrinol. 25, 1835-1848. doi: 10.1210/me.2011-1197

Herroon, M. K., Rajagurubandara, E., Hardaway, A. L., Powell, K., Turchick, A., Feldmann, D., et al. (2013). Bone marrow adipocytes promote tumor growth in bone via FABP4-dependent mechanisms. Oncotarget 4, 2108-2123.

Hinz, B., Ramer, R., Eichele, K., Weinzierl, U., and Brune, K. (2004). Up-regulation of cyclooxygenase-2 expression is involved in $\mathrm{R}(+)$-methanandamideinduced apoptotic death of human neuroglioma cells. Mol. Pharmacol. 66, 1643-1651.

Holland, M. L., Lau, D. T., Allen, J. D., and Arnold, J. C. (2007). The multidrug transporter ABCG2 (BCRP) is inhibited by plant-derived cannabinoids. Br. J. Pharmacol. 152, 815-824.

Holland, M. L., Panetta, J. A., Hoskins, J. M., Bebawy, M., Roufogalis, B. D., Allen, J. D., et al. (2006). The effects of cannabinoids on P-glycoprotein transport and expression in multidrug resistant cells. Biochem. Pharmacol. 71, 1146-1154.

Hong, Y., Zhou, Y., Wang, Y., Xiao, S., Liao, D. J., and Zhao, Q. (2013). PPAR $\gamma$ mediates the effects of WIN55,212-2, a synthetic cannabinoid, on the proliferation and apoptosis of the BEL-7402 hepatocarcinoma cells. Mol. Biol. Rep. 40, 6287-6293. doi: 10.1007/s11033-013-2741-x

Huang, H., McIntosh, A. L., Martin, G. G., Dangott, L. J., Kier, A. B., and Schroeder, F. (2018). Structural and functional interaction of $\Delta$ (9)-tetrahydrocannabinol 
with liver fatty acid binding protein (FABP1). Biochemistry 57, 6027-6042. doi: 10.1021/acs.biochem.8b00744

Huang, H., McIntosh, A. L., Martin, G. G., Landrock, D., Chung, S., Landrock, K. K., et al. (2016). FABP1: a novel hepatic endocannabinoid and cannabinoid binding protein. Biochemistry 55, 5243-5255. doi: 10.1021/acs.biochem. 6b00446

Huang, S. M., Bisogno, T., Trevisani, M., Al-Hayani, A., De Petrocellis, L., Fezza, F., et al. (2002). An endogenous capsaicin-like substance with high potency at recombinant and native vanilloid VR1 receptors. Proc. Natl. Acad. Sci. U.S.A. $99,8400-8405$.

Iannotti, F. A., Di Marzo, V., and Petrosino, S. (2016). Endocannabinoids and endocannabinoid-related mediators: targets, metabolism and role in neurological disorders. Prog. Lipid Res. 62, 107-128. doi: 10.1016/j.plipres.2016. 02.002

Inoue, M., Takahashi, Y., Fujii, T., Kitagawa, M., and Fukusato, T. (2014). Significance of downregulation of liver fatty acid-binding protein in hepatocellular carcinoma. World J. Gastroenterol. 20, 17541-17551. doi: 10. 3748/wjg.v20.i46.17541

Izzo, A. A., Aviello, G., Petrosino, S., Orlando, P., Marsicano, G., Lutz, B., et al. (2008). Increased endocannabinoid levels reduce the development of precancerous lesions in the mouse colon. J. Mol. Med. (Berl.) 86, 89-98.

Jacobsson, S. O., Wallin, T., and Fowler, C. J. (2001). Inhibition of rat C6 glioma cell proliferation by endogenous and synthetic cannabinoids, relative involvement of cannabinoid and vanilloid receptors. J. Pharmacol. Exp. Ther. 299, 951-959.

Jin, X. H., Okamoto, Y., Morishita, J., Tsuboi, K., Tonai, T., and Ueda, N. (2007). Discovery and characterization of a $\mathrm{Ca}^{2+}$-independent phosphatidylethanolamine $\mathrm{N}$-acyltransferase generating the anandamide precursor and its congeners. J. Biol. Chem. 282, 3614-3623.

Johns, D. G., Behm, D. J., Walker, D. J., Ao, Z., Shapland, E. M., Daniels, D. A., et al. (2007). The novel endocannabinoid receptor GPR55 is activated by atypical cannabinoids but does not mediate their vasodilator effects. Br. J. Pharmacol. $152,825-831$.

Jung, C. K., Kang, W. K., Park, J. M., Ahn, H. J., Kim, S. W., Taek, et al. (2013). Expression of the cannabinoid type I receptor and prognosis following surgery in colorectal cancer. Oncol. Lett. 5, 870-876.

Kaczocha, M., Glaser, S. T., and Deutsch, D. G. (2009). Identification of intracellular carriers for the endocannabinoid anandamide. Proc. Natl. Acad. Sci. U.S.A. 106, 6375-6380. doi: 10.1073/pnas.0901515106

Kaczocha, M., Glaser, S. T., Maher, T., Clavin, B., Hamilton, J., O’Rourke, J., et al. (2015). Fatty acid binding protein deletion suppresses inflammatory pain through endocannabinoid/N-acylethanolamine-dependent mechanisms. Mol. Pain. 11:52. doi: 10.1186/s12990-015-0056-8

Kaczocha, M., Rebecchi, M. J., Ralph, B. P., Teng, Y. H., Berger, W. T., Galbavy, W., et al. (2014). Inhibition of fatty acid binding proteins elevates brain anandamide levels and produces analgesia. PLoS One 9:e94200. doi: 10.1371/journal.pone. 0094200

Kaczocha, M., Vivieca, S., Sun, J., Glaser, S. T., and Deutsch, D. G. (2012). Fatty acid-binding proteins transport $\mathrm{N}$-acylethanolamines to nuclear receptors and are targets of endocannabinoid transport inhibitors. J. Biol. Chem. 287, 3415-3424. doi: 10.1074/jbc.M111.304907

Kalgutkar, A. S., Crews, B. C., Rowlinson, S. W., Garner, C., and Marnett, L. J. (1999). Discovery of a new class of selective cyclooxygenase-2 (COX-2) inhibitor that covalently modifies the isozyme. Adv. Exp. Med. Biol. 469, 139-143.

Kannan-Thulasiraman, P., Seachrist, D. D., Mahabeleshwar, G. H., Jain, M. K., and Noy, N. (2010). Fatty acid-binding protein 5 and PPARbeta/delta are critical mediators of epidermal growth factor receptor-induced carcinoma cell growth. J. Biol. Chem. 285, 19106-19115. doi: 10.1074/jbc.M109.099770

Kargl, J., Andersen, L., Hasenöhrl, C., Feuersinger, D., Stanèiæ, A., Fauland, A., et al. (2016). GPR55 promotes migration and adhesion of colon cancer cells indicating a role in metastasis. Br. J. Pharmacol. 173, 142-154. doi: 10.1111/ bph. 13345

Kawaguchi, K., Kinameri, A., Suzuki, S., Senga, S., Ke, Y., and Fujii, H. (2016). The cancer-promoting gene fatty acid-binding protein 5 (FABP5) is epigenetically regulated during human prostate carcinogenesis. Biochem. J. 473, 449-461. doi: 10.1042/BJ20150926
Kenyon, J., Liu, W., and Dalgleish, A. (2018). Report of objective clinical responses of cancer patients to pharmaceutical-grade synthetic cannabidiol. Anticancer Res. 38, 5831-5835. doi: 10.21873/anticanres.12924

Klein Nulent, T. J., Van Diest, P. J., van der Groep, P., Leusink, F. K., Kruitwagen, C. L., Koole, R., et al. (2013). Cannabinoid receptor-2 immunoreactivity is associated with survival in squamous cell carcinoma of the head and neck. Br. J. Oral Maxillofac. Surg. 51, 604-609. doi: 10.1016/j.bjoms.2013. 03.015

Kozak, K. R., Rowlinson, S. W., and Marnett, L. J. (2000). Oxygenation of the endocannabinoid, 2-arachidonylglycerol, to glyceryl prostaglandins by cyclooxygenase-2. J. Biol. Chem. 275, 33744-33749.

Ku, C. Y., Liu, Y. H., Lin, H. Y., Lu, S. C., and Lin, J. Y. (2016). Liver fatty acid-binding protein (L-FABP) promotes cellular angiogenesis and migration in hepatocellular carcinoma. Oncotarget 7, 18229-18246. doi: 10.18632/ oncotarget.7571

Laezza, C., D’Alessandro, A., Paladino, S., Malfitano, A. M., Proto, M. C., Gazzerro, P., et al. (2012). Anandamide inhibits the $\mathrm{Wnt} / \beta$-catenin signalling pathway in human breast cancer MDA MB 231 cells. Eur. J. Cancer 48, 3112-3122. doi: 10.1016/j.ejca.2012.02.062

Laezza, C., Pisanti, S., Crescenzi, E., and Bifulco, M. (2006). Anandamide inhibits Cdk2 and activates Chk1 leading to cell cycle arrest in human breast cancer cells. FEBS Lett. 580, 6076-6082.

Larrinaga, G., Sanz, B., Blanco, L., Perez, I., Candenas, M. L., Pinto, F. M., et al. (2013). Cannabinoid CB1 receptor is expressed in chromophobe renal cell carcinoma and renal oncocytoma. Clin. Biochem. 46, 638-641. doi: 10.1016/j. clinbiochem.2012.12.023

Larrinaga, G., Sanz, B., Pérez, I., Blanco, L., Cándenas, M. L., Pinto, F. M. et al. (2010). Cannabinoid CB1 receptor is downregulated in clear cell renal cell carcinoma. J. Histochem. Cytochem. 58, 1129-1134. doi: 10.1369/jhc.2010. 957126

Lauckner, J. E., Jensen, J. B., Chen, H. Y., Lu, H. C., Hille, B., and Mackie, K. (2008). GPR55 is a cannabinoid receptor that increases intracellular calcium and inhibits M current. Proc. Natl. Acad. Sci. U.S.A. 105, 2699-2704. doi: 10. 1073/pnas.0711278105

Levi, L., Lobo, G., Doud, M. K., von Lintig, J., Seachrist, D., Tochtrop, G. P., et al. (2013). Genetic ablation of the fatty acid-binding protein FABP5 suppresses HER2-induced mammary tumorigenesis. Cancer Res. 73, 4770-4780. doi: 10. 1158/0008-5472.CAN-13-0384

Ligresti, A., Bisogno, T., Matias, I., De Petrocellis, L., Cascio, M. G., Cosenza, V., et al. (2003). Possible endocannabinoid control of colorectal cancer growth. Gastroenterology 125, 677-687.

Ligresti, A., Moriello, A. S., Starowicz, K., Matias, I., Pisanti, S., De Petrocellis, L., et al. (2006). Antitumor activity of plant cannabinoids with emphasis on the effect of cannabidiol on human breast carcinoma. J. Pharmacol. Exp. Ther. 318, 1375-1387.

Liu, J., Wang, L., Harvey-White, J., Huang, B. X., Kim, H. Y., Luquet, S., et al. (2008). Multiple pathways involved in the biosynthesis of anandamide. Neuropharmacology 54, 1-7.

Liu, W. M., Scott, K. A., Shamash, J., Joel, S., and Powles, T. B. (2008). Enhancing the in vitro cytotoxic activity of Delta9-tetrahydrocannabinol in leukemic cells through a combinatorial approach. Leuk. Lymphoma 49, 1800-1809. doi: 10. $1080 / 10428190802239188$

Lo Verme, J., Fu, J., Astarita, G., La Rana, G., Russo, R., Calignano, A., et al. (2005). The nuclear receptor peroxisome proliferator-activated receptoralpha mediates the anti-inflammatory actions of palmitoylethanolamide. Mol. Pharmacol. 67, 15-19.

López-Valero, I., Torres, S., Salazar-Roa, M., García-Taboada, E., HernándezTiedra, S., Guzmán, M., et al. (2018). Optimization of a preclinical therapy of cannabinoids in combination with temozolomide against glioma. Biochem. Pharmacol. 157, 275-284. doi: 10.1016/j.bcp.2018.08.023

Lu, V. B., Puhl, H. L. III, and Ikeda, S. R. (2013). N-Arachidonyl glycine does not activate G protein-coupled receptor 18 signaling via canonical pathways. Mol. Pharmacol. 83, 267-282.

Ma, C., Wu, T. T., Jiang, P. C., Li, Z. Q., Chen, X. J., Fu, K., et al. (2016). Anticarcinogenic activity of anandamide on human glioma in vitro and in vivo. Mol. Med. Rep. 13, 1558-1562. doi: 10.3892/mmr.2015.4721

Maccarrone, M., Attinà, M., Cartoni, A., Bari, M., and Finazzi-Agrò, A. (2001). Gas chromatography-mass spectrometry analysis of endogenous cannabinoids 
in healthy and tumoral human brain and human cells in culture. J. Neurochem. 76, 594-601.

Maccarrone, M., Lorenzon, T., Bari, M., Melino, G., and Finazzi-Agrò, A. (2000). Anandamide induces apoptosis in human cells via vanilloid receptors. Evidence for a protective role of cannabinoid receptors. J. Biol. Chem. 275, 31938-31945.

Maccarrone, M., Pauselli, R., Di Rienzo, M., and Finazzi-Agrò, A. (2002). Binding, degradation and apoptotic activity of stearoylethanolamide in rat C6 glioma cells. Biochem. J. 366, 137-144.

Mackie, K., Devane, W. A., and Hille, B. (1993). Anandamide, an endogenous cannabinoid, inhibits calcium currents as a partial agonist in N18 neuroblastoma cells. Mol. Pharmacol. 44, 498-503.

Martin, G. G., Chung, S., Landrock, D., Landrock, K. K., Dangott, L. J., Peng, X., et al. (2016a). Female mice are resistant to Fabpl gene ablation induced alterations in brain endocannabinoid levels. Lipids 51, 1007-1020. doi: 10.1007/ s11745-016-4175-4

Martin, G. G., Chung, S., Landrock, D., Landrock, K. K., Huang, H., Dangott, L. J., et al. (2016b). FABP-1 gene ablation impacts brain endocannabinoid system in male mice. J. Neurochem. 138, 407-422. doi: 10.1111/jnc.13664

Matsuda, L. A., Lolait, S. J., Brownstein, M. J., Young, A. C., and Bonner, T. I. (1990). Structure of a cannabinoid receptor and functional expression of the cloned cDNA. Nature 346, 561-564.

McHugh, D., Page, J., Dunn, E., and Bradshaw, H. B. (2012). $\Delta$ (9)-Tetrahydrocannabinol and $\mathrm{N}$-arachidonyl glycine are full agonists at GPR18 receptors and induce migration in human endometrial HEC-1B cells. Br. J. Pharmacol. 165, 2414-2424. doi: 10.1111/j.1476-5381.2011.01497.x

McKallip, R. J., Nagarkatti, M., and Nagarkatti, P. S. (2005). Delta-9tetrahydrocannabinol enhances breast cancer growth and metastasis by suppression of the antitumor immune response. J. Immunol. 174, 3281-3289.

Mechoulam, R., Ben-Shabat, S., Hanus, L., Ligumsky, M., Kaminski, N. E., Schatz, A. R., et al. (1995). Identification of an endogenous 2-monoglyceride, present in canine gut, that binds to cannabinoid receptors. Biochem. Pharmacol. 50, 83-90.

Melck, D., De Petrocellis, L., Orlando, P., Bisogno, T., Laezza, C., Bifulco, M., et al. (2000). Suppression of nerve growth factor Trk receptors and prolactin receptors by endocannabinoids leads to inhibition of human breast and prostate cancer cell proliferation. Endocrinology 141, 118-126.

Messalli, E. M., Grauso, F., Luise, R., Angelini, A., and Rossiello, R. (2014). Cannabinoid receptor type 1 immunoreactivity and disease severity in human epithelial ovarian tumors. Am. J. Obstet. Gynecol. 211, .e1-.e236. doi: 10.1016/j. ajog.2014.04.004

Michalski, C. W., Oti, F. E., Erkan, M., Sauliunaite, D., Bergmann, F., Pacher, P., et al. (2008). Cannabinoids in pancreatic cancer: correlation with survival and pain. Int. J. Cancer 122, 742-750.

Mimeault, M., Pommery, N., Wattez, N., Bailly, C., and Hénichart, J. P. (2003). Anti-proliferative and apoptotic effects of anandamide in human prostatic cancer cell lines: implication of epidermal growth factor receptor downregulation and ceramide production. Prostate 56, 1-12.

Mita, R., Beaulieu, M. J., Field, C., and Godbout, R. (2010). Brain fatty acid-binding protein and omega-3/omega- 6 fatty acids: mechanistic insight into malignant glioma cell migration. J. Biol. Chem. 285, 37005-37015. doi: 10.1074/jbc.M110. 170076

Morelli, M. B., Offidani, M., Alesiani, F., Discepoli, G., Liberati, S., Olivieri, A., et al. (2014). The effects of cannabidiol and its synergism with bortezomib in multiple myeloma cell lines. A role for transient receptor potential vanilloid type-2. Int. J. Cancer 134, 2534-2546. doi: 10.1002/ijc.28591

Moreno, E., Andradas, C., Medrano, M., Caffarel, M. M., Pérez-Gómez, E., BlascoBenito, S., et al. (2014). Targeting CB2-GPR55 receptor heteromers modulates cancer cell signaling. J. Biol. Chem. 289, 21960-21972. doi: 10.1074/jbc.M114. 561761

Mücke, M., Weier, M., Carter, C., Copeland, J., Degenhardt, L., Cuhls, H., et al. (2018). Systematic review and meta-analysis of cannabinoids in palliative medicine. J. Cachexia Sarcopenia Muscle 9, 220-234. doi: 10.1002/jcsm.12273

Mukhopadhyay, B., Schuebel, K., Mukhopadhyay, P., Cinar, R., Godlewski, G., Xiong, K., et al. (2015). Cannabinoid receptor 1 promotes hepatocellular carcinoma initiation and progression through multiple mechanisms. Hepatology 61, 1615-1626. doi: 10.1002/hep.27686
Mukhopadhyay, P., Baggelaar, M., Erdelyi, K., Cao, Z., Cinar, R., Fezza, F., et al. (2016). The novel, orally available and peripherally restricted selective cannabinoid CB2 receptor agonist LEI-101 prevents cisplatin-induced nephrotoxicity. Br. J. Pharmacol. 173, 446-458. doi: 10.1111/bph.13338

Munro, S., Thomas, K. L., and Abu-Shaar, M. (1993). Molecular characterization of a peripheral receptor for cannabinoids. Nature 365, 61-65.

Nabissi, M., Morelli, M. B., Amantini, C., Liberati, S., Santoni, M., Ricci-Vitiani, L., et al. (2015). Cannabidiol stimulates Aml-1a-dependent glial differentiation and inhibits glioma stem-like cells proliferation by inducing autophagy in a TRPV2-dependent manner. Int. J. Cancer 137, 1855-1869. doi: 10.1002/ijc. 29573

Nabissi, M., Morelli, M. B., Offidani, M., Amantini, C., Gentili, S., Soriani, A., et al. (2016). Cannabinoids synergize with carfilzomib, reducing multiple myeloma cells viability and migration. Oncotarget 7, 77543-77557. doi: 10 . 18632/oncotarget.12721

Nabissi, M., Morelli, M. B., Santoni, M., and Santoni, G. (2013). Triggering of the TRPV2 channel by cannabidiol sensitizes glioblastoma cells to cytotoxic chemotherapeutic agents. Carcinogenesis 34, 48-57. doi: 10.1093/carcin/ bgs 328

Nakane, S., Oka, S., Arai, S., Waku, K., Ishima, Y., Tokumura, A., et al. (2002). 2-Arachidonoyl-sn-glycero-3-phosphate, an arachidonic acid-containing lysophosphatidic acid: occurrence and rapid enzymatic conversion to 2 arachidonoyl-sn-glycerol, a cannabinoid receptor ligand, in rat brain. Arch. Biochem. Biophys. 402, 51-58.

Nevo, J., Mai, A., Tuomi, S., Pellinen, T., Pentikäinen, O. T., Heikkilä, P., et al. (2010). Mammaryderived growth inhibitor (MDGI) interacts with integrin a-subunits and suppresses integrin activity and invasion. Oncogene 29, 64526463. doi: $10.1038 /$ onc. 2010.376

Nithipatikom, K., Endsley, M. P., Isbell, M. A., Falck, J. R., Iwamoto, Y., Hillard, C. J., et al. (2004). 2-arachidonoylglycerol: a novel inhibitor of androgenindependent prostate cancer cell invasion. Cancer Res. 64, 8826-8830.

Nithipatikom, K., Isbell, M. A., Endsley, M. P., Woodliff, J. E., and Campbell, W. B. (2011). Anti-proliferative effect of a putative endocannabinoid, 2arachidonylglyceryl ether in prostate carcinoma cells. Prostaglandins Other Lipid Mediat. 94, 34-43. doi: 10.1016/j.prostaglandins.2010.12.002

Nomura, D. K., Lombardi, D. P., Chang, J. W., Niessen, S., Ward, A. M., Long, J. Z., et al. (2011a). Monoacylglycerol lipase exerts dual control over endocannabinoid and fatty acid pathways to support prostate cancer. Chem. Biol. 18, 846-856. doi: 10.1016/j.chembiol.2011.05.009

Nomura, D. K., Morrison, B. E., Blankman, J. L., Long, J. Z., Kinsey, S. G., Marcondes, M. C., et al. (2011b). Endocannabinoid hydrolysis generates brain prostaglandins that promote neuroinflammation. Science 334, 809-813. doi: $10.1126 /$ science. 1209200

Nomura, D. K., Long, J. Z., Niessen, S., Hoover, H. S., Ng, S. W., and Cravatt, B. F. (2010). Monoacylglycerol lipase regulates a fatty acid network that promotes cancer pathogenesis. Cell 140, 49-61. doi: 10.1016/j.cell.2009.11.027

Oh, D. Y., Yoon, J. M., Moon, M. J., Hwang, J. I., Choe, H., Lee, J. Y., et al. (2008). Identification of farnesyl pyrophosphate and N-arachidonylglycine as endogenous ligands for GPR92. J. Biol. Chem. 283, 21054-21064. doi: 10.1074/ jbc.M708908200

Orellana-Serradell, O., Poblete, C. E., Sánchez, C., Castellón, E. A., Gallegos, I., Huidobro, C., et al. (2015). Proapoptotic effect of endocannabinoids in prostate cancer cells. Oncol. Rep. 33, 1599-1608.

Ortega, A., García-Hernández, V. M., Ruiz-García, E., Meneses-García, A. Herrera-Gómez, A., and Aguilar-Ponce, J. L. (2016). Comparing the effects of endogenous and synthetic cannabinoid receptor agonists on survival of gastric cancer cells. Life Sci. 165, 56-62. doi: 10.1016/j.lfs.2016.09.010

O'Sullivan, S. E., Kendall, D. A., and Randall, M. D. (2006). Further characterization of the time-dependent vascular effects of delta9-tetrahydrocannabinol. J. Pharmacol. Exp. Ther. 317, 428-438.

O'Sullivan, S. E., Sun, Y., Bennett, A. J., Randall, M. D., and Kendall, D. A. (2009). Time-dependent vascular actions of cannabidiol in the rat aorta. Eur. J. Pharmacol. 612, 61-68. doi: 10.1016/j.ejphar.2009.03.010

O’Sullivan, S. E., Tarling, E. J., Bennett, A. J., Kendall, D. A., and Randall, M. D. (2005). Novel time-dependent vascular actions of delta9-tetrahydrocannabinol mediated by peroxisome proliferator-activated receptor gamma. Biochem. Biophys. Res. Commun. 337, 824-831. 
Overton, H. A., Babbs, A. J., Doel, S. M., Fyfe, M. C., Gardner, L. S., Griffin, G., et al. (2006). Deorphanization of a G protein-coupled receptor for oleoylethanolamide and its use in the discovery of small-molecule hypophagic agents. Cell Metab. 3, 167-175.

Pagano, E., Borrelli, F., Orlando, P., Romano, B., Monti, M., Morbidelli, L., et al. (2017). Pharmacological inhibition of MAGL attenuates experimental colon carcinogenesis. Pharmacol. Res. 119, 227-236. doi: 10.1016/j.phrs.2017. 02.002

Pagotto, U., Marsicano, G., Fezza, F., Theodoropoulou, M., Grübler, Y., Stalla, J., et al. (2001). Normal human pituitary gland and pituitary adenomas express cannabinoid receptor type 1 and synthesize endogenous cannabinoids: first evidence for a direct role of cannabinoids on hormone modulation at the human pituitary level. J. Clin. Endocrinol. Metab. 86, 2687-2696.

Pan, H., Mukhopadhyay, P., Rajesh, M., Patel, V., Mukhopadhyay, B., Gao, B., et al. (2009). Cannabidiol attenuates cisplatin-induced nephrotoxicity by decreasing oxidative/nitrosative stress, inflammation, and cell death. J. Pharmacol. Exp. Ther. 328, 708-714. doi: 10.1124/jpet.108.147181

Park, S. W., Hah, J. H., Oh, S. M., Jeong, W. J., and Sung, M. W. (2016). 5-lipoxygenase mediates docosahexaenoyl ethanolamide and $\mathrm{N}$-arachidonoylL-alanine-induced reactive oxygen species production and inhibition of proliferation of head and neck squamous cell carcinoma cells. BMC Cancer 16:458. doi: 10.1186/s12885-016-2499-3

Park, S. W., Kim, J. E., Oh, S. M., Cha, W. J., Hah, J. H., and Sung, M. W. (2015). Anticancer effects of anandamide on head and neck squamous cell carcinoma cells via the production of receptor-independent reactive oxygen species. Head Neck 37, 1187-1192. doi: 10.1002/hed.23727

Patsos, H. A., Greenhough, A., Hicks, D. J., Al Kharusi, M., Collard, T. J., Lane, J. D., et al. (2010). The endogenous cannabinoid, anandamide, induces COX-2dependent cell death in apoptosis-resistant colon cancer cells. Int. J. Oncol. 37, 187-193.

Pellerito, O., Calvaruso, G., Portanova, P., De Blasio, A., Santulli, A., Vento, R., et al. (2010). The synthetic cannabinoid WIN 55,212-2 sensitizes hepatocellular carcinoma cells to tumor necrosis factor-related apoptosis-inducing ligand (TRAIL)-induced apoptosis by activating p8/CCAAT/enhancer binding protein homologous protein (CHOP)/death receptor 5 (DR5) axis. Mol. Pharmacol. 77, 854-863. doi: 10.1124/mol.109.062257

Pérez-Gómez, E., Andradas, C., Blasco-Benito, S., Caffarel, M. M., García-Taboada, E., Villa-Morales, M., et al. (2015). Role of cannabinoid receptor CB2 in HER2 pro-oncogenic signaling in breast cancer. J. Natl. Cancer Inst. 107:djv077. doi: 10.1093/jnci/djv077

Petersen, G., Moesgaard, B., Schmid, P. C., Schmid, H. H., Broholm, H., Kosteljanetz, M., et al. (2005). Endocannabinoid metabolism in human glioblastomas and meningiomas compared to human non-tumour brain tissue. J. Neurochem. 93, 299-309.

Petrosino, S., and Di Marzo, V. (2010). FAAH and MAGL inhibitors: therapeutic opportunities from regulating endocannabinoid levels. Curr. Opin. Investig. Drugs 11, 51-62.

Portella, G., Laezza, C., Laccetti, P., De Petrocellis, L., Di Marzo, V., and Bifulco, M. (2003). Inhibitory effects of cannabinoid CB1 receptor stimulation on tumor growth and metastatic spreading: actions on signals involved in angiogenesis and metastasis. FASEB J. 17, 1771-1773.

Porter, A. C., Sauer, J. M., Knierman, M. D., Becker, G. W., Berna, M. J., Bao, J., et al. (2002). Characterization of a novel endocannabinoid, virodhamine, with antagonist activity at the CB1 receptor. J. Pharmacol. Exp. Ther. 301, 1020-1024.

Prescott, S. M., and Majerus, P. W. (1983). Characterization of 1,2diacylglycerol hydrolysis in human platelets. Demonstration of an arachidonoyl-monoacylglycerol intermediate. J. Biol. Chem. 258, 764-769.

Proto, M. C., Gazzerro, P., Di Croce, L., Santoro, A., Malfitano, A. M., Pisanti, S., et al. (2012). Interaction of endocannabinoid system and steroid hormones in the control of colon cancer cell growth. J. Cell. Physiol. 227, 250-258. doi: $10.1002 /$ jcp. 22727

Qin, N., Neeper, M. P., Liu, Y., Hutchinson, T. L., Lubin, M. L., and Flores, C. M. (2008). TRPV2 is activated by cannabidiol and mediates CGRP release in cultured rat dorsal root ganglion neurons. J. Neurosci. 28, 6231-6238. doi: 10.1523/JNEUROSCI.0504-08.2008

Rahmatollahi, M., Baram, S. M., Rahimian, R., Saeedi Saravi, S. S., and Dehpour, A. R. (2016). Peroxisome proliferator-activated receptor- $\alpha$ inhibition protects against doxorubicin-induced cardiotoxicity in mice. Cardiovasc. Toxicol. 16, 244-250. doi: 10.1007/s12012-015-9332-0

Ramer, R., Bublitz, K., Freimuth, N., Merkord, J., Rohde, H., Haustein, M., et al. (2012). Cannabidiol inhibits lung cancer cell invasion and metastasis via intercellular adhesion molecule-1. FASEB J. 26, 1535-1548. doi: 10.1096/fj.11198184

Ramer, R., Heinemann, K., Merkord, J., Rohde, H., Salamon, A., Linnebacher, M., et al. (2013). COX-2 and PPAR- $\gamma$ confer cannabidiol-induced apoptosis of human lung cancer cells. Mol. Cancer Ther. 12, 69-82. doi: 10.1158/1535-7163. MCT-12-0335

Ramer, R., and Hinz, B. (2008). Inhibition of cancer cell invasion by cannabinoids via increased expression of tissue inhibitor of matrix metalloproteinases-1. J. Natl. Cancer Inst. 100, 59-69.

Ramer, R., and Hinz, B. (2016). Antitumorigenic targets of cannabinoids - Current status and implications. Expert Opin. Ther. Targets 20, 1219-1235. doi: 10.1080/ 14728222.2016.1177512

Redmond, W. J., Cawston, E. E., Grimsey, N. L., Stuart, J., Edington, A. R., Glass, M., et al. (2016). Identification of $\mathrm{N}$-arachidonoyl dopamine as a highly biased ligand at cannabinoid CB1 receptors. Br. J. Pharmacol. 173, 115-127. doi: 10.1111/bph.13341

Rimmerman, N., Ben-Hail, D., Porat, Z., Juknat, A., Kozela, E., Daniels, M. P., et al. (2013). Direct modulation of the outer mitochondrial membrane channel, voltage-dependent anion channel 1 (VDAC1) by cannabidiol: a novel mechanism for cannabinoid-induced cell death. Cell Death Dis. 5:e949. doi: 10.1038/cddis.2013.471

Ross, R. A. (2011). L- $\alpha$-lysophosphatidylinositol meets GPR55: a deadly relationship. Trends Pharmacol. Sci. 32, 265-269. doi: 10.1016/j.tips.2011. 01.005

Rovito, D., Giordano, C., Vizza, D., Plastina, P., Barone, I., Casaburi, I., et al. (2013). Omega-3 PUFA ethanolamides DHEA and EPEA induce autophagy through PPAR $\gamma$ activation in MCF-7 breast cancer cells. J. Cell. Physiol. 228, 1314-1322. doi: $10.1002 /$ jcp. 24288

Ryberg, E., Larsson, N., Sjögren, S., Hjorth, S., Hermansson, N. O., Leonova, J., et al. (2007). The orphan receptor GPR55 is a novel cannabinoid receptor. Br. J. Pharmacol. 152, 1092-1101.

Saghatelian, A., Trauger, S. A., Want, E. J., Hawkins, E. G., Siuzdak, G., and Cravatt, B. F. (2004). Assignment of endogenous substrates to enzymes by global metabolite profiling. Biochemistry 43, 14332-14339.

Sailler, S., Schmitz, K., Jäger, E., Ferreiros, N., Wicker, S., Zschiebsch, K., et al. (2014). Regulation of circulating endocannabinoids associated with cancer and metastases in mice and humans. Oncoscience 1, 272-282.

Sánchez, C., de Ceballos, M. L., Gomez, del Pulgar, T., Rueda, D., Corbacho, C. et al. (2001). Inhibition of glioma growth in vivo by selective activation of the CB(2) cannabinoid receptor. Cancer Res. 61, 5784-5789.

Sanson, B., Wang, T., Sun, J., Wang, L., Kaczocha, M., Ojima, I., et al. (2014). Crystallographic study of FABP5 as an intracellular endocannabinoid transporter. Acta Crystallogr. D Biol. Crystallogr. 70, 290-298. doi: 10.1107/ S1399004713026795

Sarnelli, G., Gigli, S., Capoccia, E., Iuvone, T., Cirillo, C., Seguella, L., et al. (2016) Palmitoylethanolamide exerts antiproliferative effect and downregulates VEGF signaling in Caco-2 human colon carcinoma cell line through a selective PPAR$\gamma$-dependent inhibition of Akt/mTOR pathway. Phytother. Res. 30, 963-970. doi: $10.1002 /$ ptr.5601

Savinainen, J. R., Järvinen, T., Laine, K., and Laitinen, J. T. (2001). Despite substantial degradation, 2-arachidonoylglycerol is a potent full efficacy agonist mediating $\mathrm{CB}(1)$ receptor-dependent $\mathrm{G}$-protein activation in rat cerebellar membranes. Br. J. Pharmacol. 134, 664-672.

Schmid, H. H. (2000). Pathways and mechanisms of N-acylethanolamine biosynthesis: can anandamide be generated selectively? Chem. Phys. Lipids 108, 71-87.

Schmid, P. C., Wold, L. E., Krebsbach, R. J., Berdyshev, E. V., and Schmid, H. H. (2002). Anandamide and other $\mathrm{N}$-acylethanolamines in human tumors. Lipids 37, 907-912.

Schwarz, R., Ramer, R., and Hinz, B. (2018). Targeting the endocannabinoid system as a potential anticancer approach. Drug Metab. Rev. 50, 26-53. doi: 10.1080/ 03602532.2018 .1428344 
Slipetz, D. M., O’Neill, G. P., Favreau, L., Dufresne, C., Gallant, M., Gareau, Y., et al. (1995). Activation of the human peripheral cannabinoid receptor results in inhibition of adenylyl cyclase. Mol. Pharmacol. 48, 352-361.

Song, G. X., Shen, Y. H., Liu, Y. Q., Sun, W., Miao, L. P., Zhou, L. J., et al. (2012). Overexpression of FABP3 promotes apoptosis through inducing mitochondrial impairment in embryonic cancer cells. J. Cell Biochem. 113, 3701-3708. doi: $10.1002 /$ jcb. 24243

Steffens, M., Schulze-Bonhage, A., Surges, R., and Feuerstein, T. J. (2005). Fatty acid amidohydrolase in human neocortex-activity in epileptic and non-epileptic brain tissue and inhibition by putative endocannabinoids. Neurosci. Lett. 385 , 13-17.

Stella, N., Schweitzer, P., and Piomelli, D. (1997). A second endogenous cannabinoid that modulates long-term potentiation. Nature 388, 773-778.

Sugiura, T., Kodaka, T., Nakane, S., Miyashita, T., Kondo, S., Suhara, Y., et al. (1999). Evidence that the cannabinoid CB1 receptor is a 2-arachidonoylglycerol receptor. Structure-activity relationship of 2-arachidonoylglycerol, ether-linked analogues, and related compounds. J. Biol. Chem. 274, 2794-2801.

Sugiura, T., Kondo, S., Kishimoto, S., Miyashita, T., Nakane, S., Kodaka, T., et al. (2000). Evidence that 2-arachidonoylglycerol but not N-palmitoylethanolamine or anandamide is the physiological ligand for the cannabinoid CB2 receptor. Comparison of the agonistic activities of various cannabinoid receptor ligands in HL-60 cells. J. Biol. Chem. 275, 605-612.

Sugiura, T., Kondo, S., Sukagawa, A., Nakane, S., Shinoda, A., Itoh, K., et al. (1995). 2-Arachidonoylglycerol: a possible endogenous cannabinoid receptor ligand in brain. Biochem. Biophys. Res. Commun. 215, 89-97.

Sun, H., Jiang, L., Luo, X., Jin, W., He, Q., An, J., et al. (2013). Potential tumorsuppressive role of monoglyceride lipase in human colorectal cancer. Oncogene 32, 234-241. doi: 10.1038/onc.2012.34

Sun, Y., Alexander, S. P., Garle, M. J., Gibson, C. L., Hewitt, K., Murphy, S. P., et al. (2007). Cannabinoid activation of PPAR alpha; a novel neuroprotective mechanism. Br. J. Pharmacol. 152, 734-743.

Sun, Y. X., Tsuboi, K., Zhao, L. Y., Okamoto, Y., Lambert, D. M., and Ueda, N. (2005). Involvement of $\mathrm{N}$-acylethanolamine-hydrolyzing acid amidase in the degradation of anandamide and other $\mathrm{N}$-acylethanolamines in macrophages. Biochim. Biophys. Acta 1736, 211-220.

Takeda, S., Ikeda, E., Su, S., Harada, M., Okazaki, H., Yoshioka, Y., et al. (2014). $\Delta(9)$-THC modulation of fatty acid 2-hydroxylase (FA2H) gene expression: possible involvement of induced levels of PPAR $\gamma$ in MDA-MB-231 breast cancer cells. Toxicology 326, 18-24.

Tellez, L. A., Medina, S., Han, W., Ferreira, J. G., Licona-Limón, P., Ren, X., et al. (2013). A gut lipid messenger links excess dietary fat to dopamine deficiency. Science 341, 800-802. doi: 10.1126/science.1239275

Thors, L., Bergh, A., Persson, E., Hammarsten, P., Stattin, P., Egevad, L., et al. (2010). Fatty acid amide hydrolase in prostate cancer: association with disease severity and outcome. CB1 receptor expression and regulation by IL-4. PLoS One 5:e12275. doi: 10.1371/journal.pone.0012275

Thumser, A. E., Moore, J. B., and Plant, N. J. (2014). Fatty acid binding proteins: tissue-specific functions in health and disease. Curr. Opin. Clin. Nutr. Metab. Care 17, 124-129. doi: 10.1097/MCO.0000000000000031

Tölle, A., Jung, M., Lein, M., Johannsen, M., Miller, K., Moch, H., et al. (2009). Brain-type and liver-type fatty acid-binding proteins: new tumor markers for renal cancer? BMC Cancer 9:248. doi: 10.1186/1471-2407-9-248

Torres, S., Lorente, M., Rodríguez-Fornés, F., Hernández-Tiedra, S., Salazar, M., García-Taboada, E., et al. (2011). A combined preclinical therapy of cannabinoids and temozolomide against glioma. Mol. Cancer Ther. 10, 90-103. doi: 10.1158/1535-7163.MCT-10-0688

Ueda, N., Yamanaka, K., Terasawa, Y., and Yamamoto, S. (1999). An acid amidase hydrolyzing anandamide as an endogenous ligand for cannabinoid receptors. FEBS Lett. 454, 267-270.

Uehara, H., Takahashi, T., Oha, M., Ogawa, H., and Izumi, K. (2014). Exogenous fatty acid binding protein 4 promotes human prostate cancer cell progression. Int. J. Cancer 135, 2558-2568. doi: 10.1002/ijc.28903

Vago, R., Bettiga, A., Salonia, A., Ciuffreda, P., and Ottria, R. (2017). Development of new inhibitors for $\mathrm{N}$-acylethanolamine-hydrolyzing acid amidase as promising tool against bladder cancer. Bioorg. Med. Chem. 25, 1242-1249.

Vara, D., Morell, C., Rodríguez-Henche, N., and Diaz-Laviada, I. (2013). Involvement of PPAR $\gamma$ in the antitumoral action of cannabinoids on hepatocellular carcinoma. Cell Death Dis. 4, e618. doi: 10.1038/cddis.2013.141
Wallace, M. S., Marcotte, T. D., Umlauf, A., Gouaux, B., and Atkinson, J. H. (2015). Efficacy of inhaled cannabis on painful diabetic neuropathy. J. Pain 16, 616-627. doi: 10.1016/j.jpain.2015.03.008

Wang, B., Tao, X., Huang, C. Z., Liu, J. F., Ye, Y. B., and Huang, A. M. (2014). Decreased expression of liver-type fatty acid-binding protein is associated with poor prognosis in hepatocellular carcinoma. Hepatogastroenterology 61, 1321-1326.

Wang, D., Wang, H., Ning, W., Backlund, M. G., Dey, S. K., and DuBois, R. N. (2008). Loss of cannabinoid receptor 1 accelerates intestinal tumor growth. Cancer Res. 68, 6468-6476. doi: 10.1158/0008-5472.CAN-080896

Wang, J., and Ueda, N. (2009). Biology of endocannabinoid synthesis system. Prostaglandins Other Lipid Mediat. 89, 112-119. doi: 10.1016/j.prostaglandins. 2008.12.002

Wang, J., Xu, Y., Zhu, L., Zou, Y., Kong, W., Dong, B., et al. (2018). Cannabinoid receptor 2 as a novel target for promotion of renal cell carcinoma prognosis and progression. J. Cancer Res. Clin. Oncol. 144, 39-52. doi: 10.1007/s00432-0172527-y

Wang, J., Xu, Y., Zou, Y., Zhu, L., Dong, B., Huang, J., et al. (2016). Overexpression of cannabinoid receptor 1 promotes renal cell carcinoma progression. Tumour Biol.

Wang, J., Zhao, L. Y., Uyama, T., Tsuboi, K., Wu, X. X., Kakehi, Y., et al. (2008). Expression and secretion of $\mathrm{N}$-acylethanolamine-hydrolysing acid amidase in human prostate cancer cells. J. Biochem. 144, 685-690. doi: 10.1093/jb/mvn122

Wang, W., Chu, H. J., Liang, Y. C., Huang, J. M., Shang, C. L., Tan, H., et al. (2016). FABP5 correlates with poor prognosis and promotes tumor cell growth and metastasis in cervical cancer. Tumour Biol. 37, 14873-14883.

Wang, Y. T., Liu, C. H., and Zhu, H. L. (2016). Fatty acid binding protein (FABP) inhibitors: a patent review (2012-2015). Expert Opin. Ther. Pat. 26, 767-776. doi: 10.1080/13543776.2016.1182500

Whiting, P. F., Wolff, R. F., Deshpande, S., Di Nisio, M., Duffy, S., Hernandez, A. V., et al. (2015). Cannabinoids for medical use: a systematic review and meta-analysis. JAMA 313, 2456-2473. doi: 10.1001/jama.2015.6358

Winkler, K., Ramer, R., Dithmer, S., Ivanov, I., Merkord, J., and Hinz, B. (2016). Fatty acid amide hydrolase inhibitors confer anti-invasive and antimetastatic effects on lung cancer cells. Oncotarget 7, 15047-15064. doi: 10.18632/ oncotarget.7592

Wu, X., Han, L., Zhang, X., Li, L., Jiang, C., Qiu, Y., et al. (2012). Alteration of endocannabinoid system in human gliomas. J. Neurochem. 120, 842-849. doi: 10.1111/j.1471-4159.2011.07625.x

Xu, X., Liu, Y., Huang, S., Liu, G., Xie, C., Zhou, J., et al. (2006). Overexpression of cannabinoid receptors $\mathrm{CB} 1$ and $\mathrm{CB} 2$ correlates with improved prognosis of patients with hepatocellular carcinoma. Cancer Genet. Cytogenet. 171, 31-38.

Yan, F., Shen, N., Pang, J. X., Zhang, Y. W., Rao, E. Y., Bode, A. M., et al. (2017). Fatty acid-binding protein FABP4 mechanistically links obesity with aggressive AML by enhancing aberrant DNA methylation in AML cells. Leukemia 31, 1434-1442. doi: 10.1038/leu.2016.349

Ye, L., Zhang, B., Seviour, E. G., Tao, K. X., Liu, X. H., Ling, Y., et al. (2011). Monoacylglycerol lipase (MAGL) knockdown inhibits tumor cells growth in colorectal cancer. Cancer Lett. 307, 6-17. doi: 10.1016/j.canlet.2011.03.007

Yin, H., Chu, A., Li, W., Wang, B., Shelton, F., Otero, F., et al. (2009). Lipid G protein-coupled receptor ligand identification using beta-arrestin PathHunter assay. J. Biol. Chem. 284, 12328-12338. doi: 10.1074/jbc.M806516200

Yousef, B. A., Hassan, H. M., Zhang, L. Y., and Jiang, Z. Z. (2017). Anticancer potential and molecular targets of pristimerin: a minireview. Curr. Cancer Drug Targets 17, 100-108. doi: 10.2174/1568009616666160112105824

Yu, M., Ives, D., and Ramesha, C. S. (1997). Synthesis of prostaglandin E2 ethanolamide from anandamide by cyclooxygenase-2. J. Biol. Chem. 272, 21181-21186.

Zhang, J., Medina-Cleghorn, D., Bernal-Mizrachi, L., Bracci, P. M., Hubbard, A., Conde, L., et al. (2016). The potential relevance of the endocannabinoid, 2 -arachidonoylglycerol, in diffuse large B-cell lymphoma. Oncoscience 3, 31-41.

Zhang, W., Levi, L., Banerjee, P., Jain, M., and Noy, N. (2015). Kruppel-like factor 2 suppresses mammary carcinoma growth by regulating retinoic acid signaling. Oncotarget 6, 35830-35842. doi: 10.18632/oncotarget.5767

Zhu, L. X., Sharma, S., Stolina, M., Gardner, B., Roth, M. D., Tashkin, D. P., et al. (2000). Delta-9-tetrahydrocannabinol inhibits antitumor immunity by 
a CB2 receptor-mediated, cytokine-dependent pathway. J. Immunol. 165, 373-380.

Zhu, W., Zhao, Y., Zhou, J., Wang, X., Pan, Q., Zhang, N., et al. (2016). Monoacylglycerol lipase promotes progression of hepatocellular carcinoma via NF-кB-mediated epithelial-mesenchymal transition. J. Hematol. Oncol. 9:127.

Zygmunt, P. M., Petersson, J., Andersson, D. A., Chuang, H., Sørgård, M., Di Marzo, V., et al. (1999). Vanilloid receptors on sensory nerves mediate the vasodilator action of anandamide. Nature 400, $452-457$.
Conflict of Interest Statement: The authors declare that the research was conducted in the absence of any commercial or financial relationships that could be construed as a potential conflict of interest.

Copyright (c) 2019 Ramer, Schwarz and Hinz. This is an open-access article distributed under the terms of the Creative Commons Attribution License (CC BY). The use, distribution or reproduction in other forums is permitted, provided the original author(s) and the copyright owner(s) are credited and that the original publication in this journal is cited, in accordance with accepted academic practice. No use, distribution or reproduction is permitted which does not comply with these terms. 